\title{
Origin of the Rubian carbonate-hosted magnesite deposit, Galicia, NW Spain: mineralogical, REE, fluid inclusion and isotope evidence
}

\author{
Stephanos P. Kilias - Manuel Pozo - Manuel Bustillo •
}

Michael G. Stamatakis · José P. Calvo

\begin{abstract}
The Rubian magnesite deposit (West Asturian - Leonese Zone, Iberian Variscan belt) is hosted by a 100- m-thick folded and metamorphosed Lower Cambrian carbonate/siliciclastic metasedimentary sequence-the Cándana Limestone Formation. It comprises upper (20$\mathrm{m}$ thickness) and lower (17-m thickness) lens-shaped ore bodies separated by $55 \mathrm{~m}$ of slates and micaceous schists. The main (lower) magnesite ore body comprises a package of magnesite beds with dolomite-rich intercalations, sandwiched between slates and micaceous schists. In the upper ore body, the magnesite beds are thinner (centimetre scale mainly) and occur between slate beds. Mafic dolerite dykes intrude the mineralisation. The mineralisation passes eastwards into sequence of bedded dolostone (Buxan) and laminated to banded calcitic marble (Mao). These show significant Variscan extensional shearing or fold-related deformation, whereas neither Rubian dolomite nor magnesite show evidence of tectonic disturbance. This suggests that the dolomitisa-
\end{abstract}

S. P. Kilias (*) · M. G. Stamatakis

Department of Economic Geology and Geochemistry, Faculty of Geology and Geoenvironment,

National and Kapodistrian University of Athens (NKUA), Panepistimioupolis, Zographou,

15784 Athens, Greece

e-mail: kilias@geol.uoa.gr

Tel.: +30-2107274211

Fax: $+30-2107274399$

M. Pozo

Departamento de Quimica Agricola, Geología y Geoquímica, Universidad Autónoma,

Cantoblanco, 28049 Madrid, Spain

M. Bustillo

Departamento de Petrología y Geoquímica,

Universidad Complutense,

28040 Madrid, Spain

J. P. Calvo

Instituto Geologico y Minero de Espana,

c/Rios Rosas 23,

28003 Madrid, Spain tion and magnesite formation postdate the main Variscan deformation. In addition, the morphology of magnesite crystals and primary fluid inclusions indicate that magnesite is a neoformed hydrothermal mineral. Magnesite contains irregularly distributed dolomite inclusions $(<50 \mu \mathrm{m})$ and these are interpreted as relics of a metasomatically replaced dolostone precursor. The total rare earth element (REE) contents of magnesite are very similar to those of Buxan dolostone but are depleted in light rare earth elements (LREE); heavy rare earth element concentrations are comparable. However, magnesite REE chondrite normalised profiles lack any characteristic anomaly indicative of marine environment. Compared with Mao calcite, magnesite is distinct in terms of both REE concentrations and patterns. Fluid inclusion studies show that the mineralising fluids were $\mathrm{MgCl}_{2}-\mathrm{NaCl}-$ $\mathrm{CaCl}_{2}-\mathrm{H}_{2} \mathrm{O}$ aqueous brines exhibiting highly variable salinities (3.3 to 29.5 wt.\% salts). This may be the result of a combination of fluid mixing, migration of pulses of variable-salinity brines and/or local dissolution and replacement processes of the host dolostone. Fluid inclusion data and comparison with other $\mathrm{N}$ Iberian dolostone-hosted metasomatic deposits suggest that Rubian magnesite probably formed at temperatures between 160 and $200^{\circ} \mathrm{C}$. This corresponds, at hydrostatic pressure (500 bar), to a depth of formation of $\sim 5 \mathrm{~km}$. Mineralisation-related Rubian dolomite yields $\delta^{18} \mathrm{O}$ values $\left(\delta^{18} \mathrm{O}\right.$ : $12.0-15.4 \%$ o, mean: $14.4 \pm 1.1 \%$ o) depleted by around $5 \%$ o compared with barren Buxan dolomite $\left(\delta^{18} \mathrm{O}\right.$ : 17.1$20.2 \%$, mean: $19.4 \pm 1.0 \%$ o). This was interpreted to reflect an influx of ${ }^{18} \mathrm{O}$-depleted waters accompanied by a temperature increase in a fluid-dominated system. Overlapping calculated $\delta^{18} \mathrm{O}_{\text {fluid }}$ values $\left(\sim+5 \%\right.$ at $\left.200^{\circ} \mathrm{C}\right)$ for fluids in equilibrium with Rubian dolomite and magnesite show that they were formed by the same hydrothermal system at different temperatures. In terms of $\delta^{13} \mathrm{C}$ values, Rubian dolomite $\left(\delta^{13} \mathrm{C}\right.$ : -1.4 to $1.9 \%$, mean: $0.4 \pm 1.3 \%$ ) and magnesite $\left(\delta^{13} \mathrm{C}\right.$ : -2.3 to $2.4 \%$, mean: $0.60 \pm 1.0 \%$ o generally exhibit more negative $\delta^{13} \mathrm{C}$ values compared with Buxan dolomite $\left(\delta^{13} \mathrm{C}\right.$ : -0.2 to $1.9 \%$, mean: $0.8 \pm$ $0.6 \%$ ) and Mao calcite $\left(\delta^{13} \mathrm{C}:-0.3\right.$ to $1.5 \%$, mean: $0.6 \pm$ 
$0.6 \%$ ), indicating progressive modification to lower $\delta^{13} \mathrm{C}$ values through interaction with hydrothermal fluids. ${ }^{87} \mathrm{Sr} /{ }^{86} \mathrm{Sr}$ ratios, calculated at $290 \mathrm{Ma}$, vary from 0.70849 to 0.70976 for the Mao calcite and from 0.70538 to 0.70880 for the Buxan dolostone. The ${ }^{87} \mathrm{Sr} /{ }^{86} \mathrm{Sr}$ ratios in Rubian magnesite are more radiogenic and range from 0.71123 to 0.71494 . The combined $\delta^{18} \mathrm{O}-\delta^{13} \mathrm{C}$ and ${ }^{87} \mathrm{Sr} /{ }^{86} \mathrm{Sr}$ data indicate that the magnesite-related fluids were modified basinal brines that have reacted and equilibrated with intercalated siliciclastic rocks. Magnesite formation is genetically linked to regional hydrothermal dolomitisation associated with lithospheric delamination, late-Variscan high heat flow and extensional tectonics in the NW Iberian Belt. A comparison with genetic models for the Puebla de Lillo talc deposits suggests that the formation of hydrothermal replacive magnesite at Rubian resulted from a metasomatic column with magnesite forming at higher fluid/rock ratios than dolomite. In this study, magnesite generation took place via the local reaction of hydrothermal dolostone with the same hydrothermal fluids in very high permeability zones at high fluid/rock ratios (e.g. faults). It was also possibly aided by additional heat from intrusive dykes or sub-cropping igneous bodies. This would locally raise isotherms enabling a transition from the dolomite stability field to that of magnesite.

Keywords Spain $\cdot$ Magnesite $\cdot$ Rubian $\cdot$ Dolomitisation

\section{Introduction}

The Rubian magnesite deposit with $~ 10 \mathrm{Mt}$ and $43 \mathrm{wt} \%$ MgO (Instituto Geologico Y Minero de Espana-IGME 1983), located $9 \mathrm{~km}$ south of Sarria in Galicia, and the Eugui-Asturreta deposit in Navarra ( $\sim 20 \mathrm{Mt}$ and $39 \mathrm{wt} \%$ MgO) (Gómez de Llarena 1959; Velasco et al. 1987; Lugli et al. 2000) are the only magnesite deposits currently mined in Spain. The Rubian deposit is currently operated by Magnesitas de Rubian S.A.- - total annual production at Rubian reaches 150,000 tonnes and with Eugui it is $\sim 650,000$ tonnes (IGME unpublished, in Sanchez-España et al. 2002). The new Borovia magnesite deposit was recently discovered in Soria, with $>175 \mathrm{Mt}$ and 36-47 wt\% MgO (Sanchez-España et al. 2002), thus adding considerably to the Spanish exploitable magnesite resources. The Rubian deposit as well as the Eugui and Borovia deposits occur in tectonised and metamorphosed Palaeozoic carbonate rocks and, therefore, offers a very good opportunity to study the enigmatic mode(s) of formation of this class of magnesite deposits (e.g. Lugli et al. 2000, 2002 and references therein).

Controversy surrounds the genesis of sparry magnesite deposits hosted by carbonate rocks in tectonised and metamorphosed terrains. There are those who support a syngenetic origin (e.g. Niedermayr et al. 1983; Pohl 1990; Melezhik et al. 2001), which implies deposition of magnesite under evaporitic conditions or during diagenetic transformation of a magnesite protolith, and others who favour an epigenetic origin (e.g. Morteani et al. 1983; Velasco et al. 1987; Aharon 1988; Ellmies et al. 1999; Lugli et al. 2000, 2002), which involves hydrothermal/metasomatic replacement of dolostone "during a thermal event" locally involving thrust tectonics and metamorphism.

This study deals with geological, mineralogical, rare earth element (REE), fluid inclusion and isotope data of the Rubian magnesite mineralisation and its host rocks, in an attempt to decipher the origin of this deposit in relation to the current genetic theories.

\section{Geological setting}

The Rubian magnesite deposit is located $9 \mathrm{~km}$ south of Sarria on the southern edge of the Mondoñedo Nappe (MON) which occupies the western part of the West Asturian Leonese Zone (WALZ) (Dallmeyer and MartínezGarcia 1990) (Fig. 1a). The WALZ is the transition between the Cantabrian (east) and the Central Iberian Zones (CIZ) (west) which collectively comprise the NW Iberian Variscan Massif (Fig. 1a). To the west, the Mondoñedo Nappe is bounded by the Viveiro Fault (Fig. 1a) dated at 295-310 Ma that cuts across the thrust and juxtaposes the MON with the CIZ (Martínez Catalán et al. 1992).

Studies of the tectonometamorphic evolution of the WALZ have revealed a complex succession of Variscan deformation and metamorphic episodes (Dallmeyer et al. 1997; Martínez Catalán et al. 1990, 2003; Marcos et al. 2004). The MON is a large crystalline thrust sheet, formed essentially by low- to high-grade metasediments ranging in age from Late Proterozoic to Early Devonian (Arenas and Martínez Catalán 2003). The stratigraphic succession in the MON consists of ca. 3,000-m thick Precambrian (Late Proterozoic) slates and greywackes, unconformably overlain by a 3,000-m thick stratigraphic succession of Early Cambrian to Early Devonian metasediments; the slates are the most common lithologies followed by quartzites and carbonates (Martínez Catalán et al. 2003; Marcos et al. 2004). The Rubian magnesite deposit is hosted in the Early Cambrian "Cándana Limestone Formation" that constitutes the lower part of the Cándana Group (Fig. 1b) (Lotze 1957; Walter 1968).

The Palaeozoic platform carbonate rocks hosting the Rubian deposit underwent a first episode of Variscan eastverging recumbent folding loosely constrained between 360 and 335 Ma that formed the Mondonedo-Lugo-Sarria anticline. According to Martínez Catalán et al. (2003), this event was accompanied by the development of mediumpressure regional metamorphism $\left(\mathrm{M}_{1}\right)$ with $P_{\text {peak }}$ : 2-6 kbar and $T_{\text {peak }}>680^{\circ} \mathrm{C}$ with Barrovian-type metamorphic zonation. The MON subsequently suffered low-grade retrograde metamorphism $\left(\mathrm{M}_{2}\right)$ characterised by decom-

Fig. 1 a Geological map of the NW Variscan belt of Spain showing" the location of the study area (box) (modified from Arenas and Martínez Catalán 2003). b Schematic map of the study area showing the location of the Rubian deposit (modified from Martínez Catalán and Pablo 1978) 


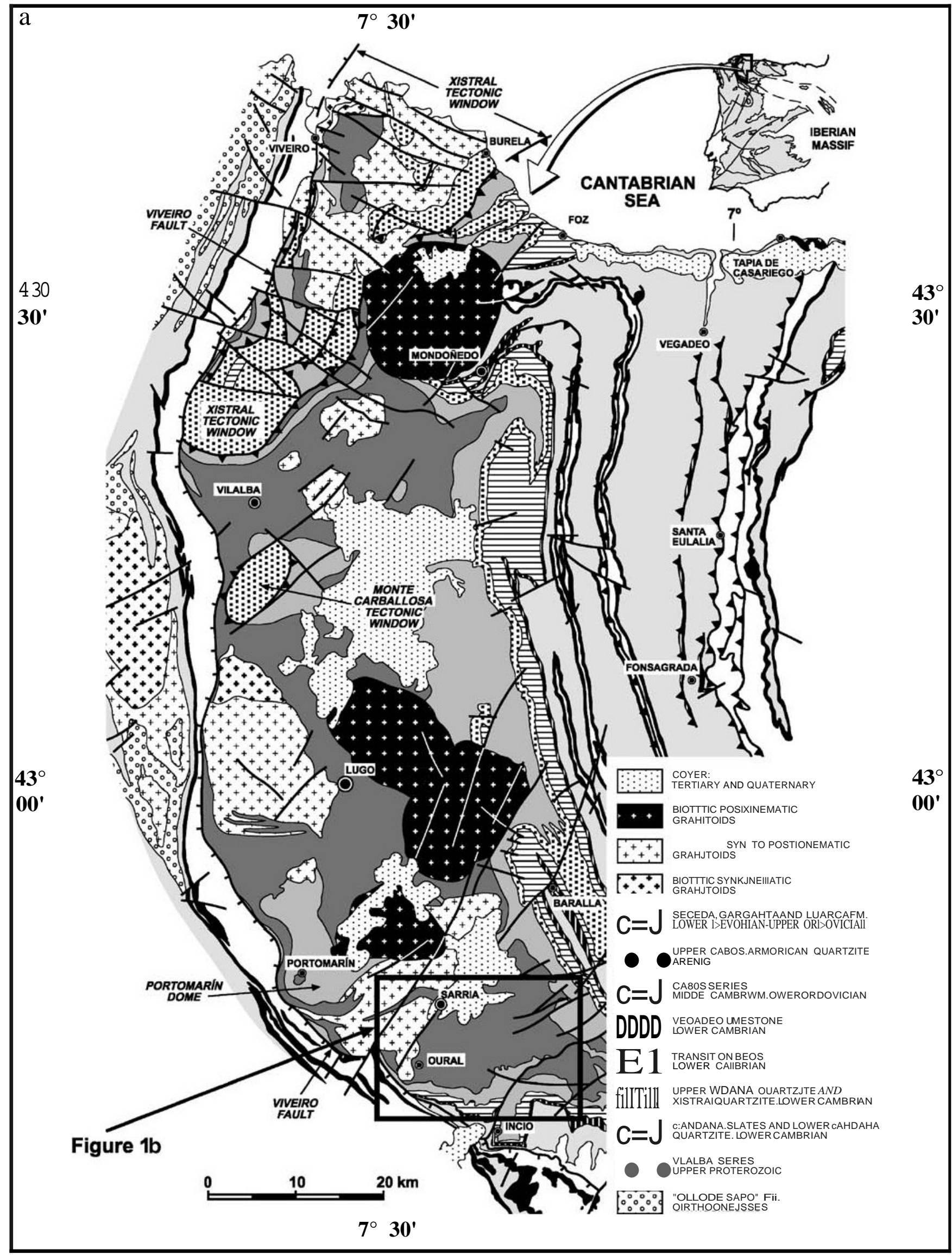


Fig. 1 (continued)

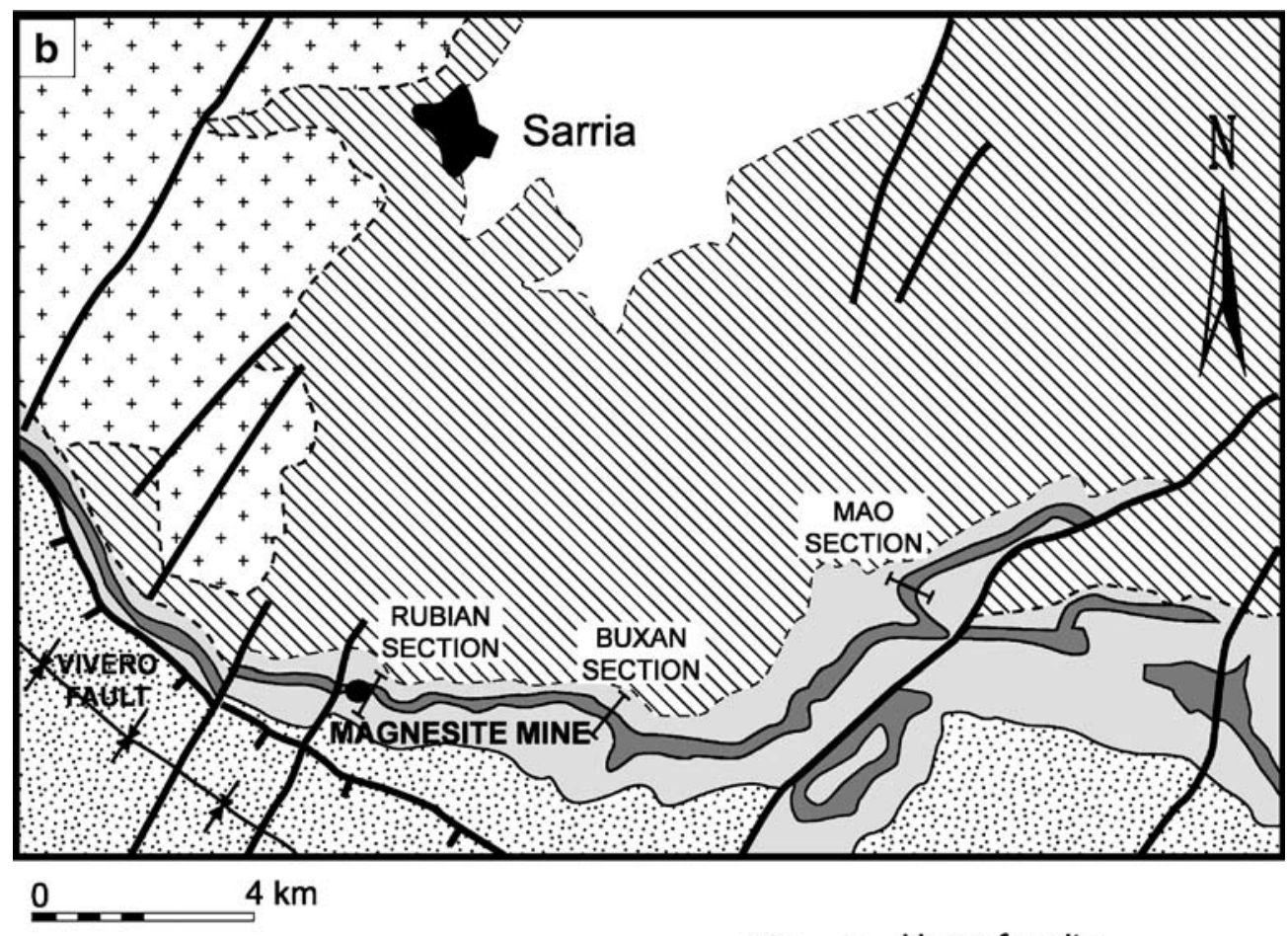

\section{$\therefore \because \ldots$ Unconformity}
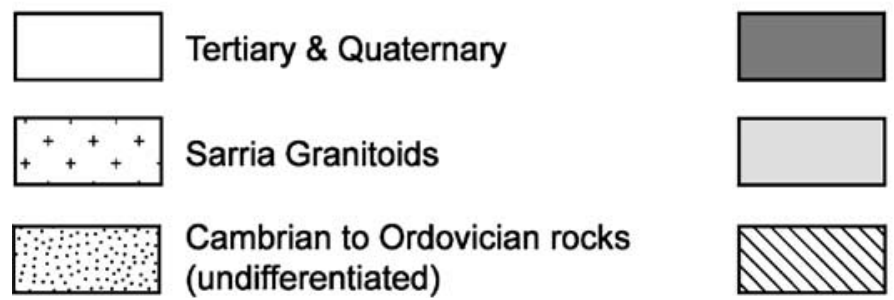

Cándana Limestone $\mathrm{Fm}$. (Lower Cambrian)

\section{Cándana Group (Lower Cambrian)} (undifferentiated)

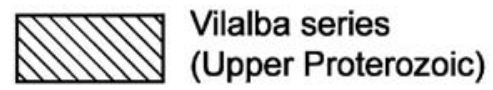

Geology of the magnesite deposit

pression down to $\mathrm{P}_{2}$ : $1-2 \mathrm{kbar}$ and $T_{2}<380-480^{\circ} \mathrm{C}$ and related to uplift and exhumation. Extension synchronous with $\mathrm{M}_{2}$ developed along major ductile shear zones within the MON, between 340 and $310 \mathrm{Ma}$, and produced subhorizontal crenulation cleavage as well as an E-W mineral lineation (Martínez Catalán et al. 2003).

Syn- and post-tectonic plutons intruded the MON during two magmatic episodes dated at 325-310 and 295-285 Ma, respectively (Fernández-Suarez et al. 2000; Aranguren et al. 2003; Arenas and Martínez-Catalán 2003). The Sarria syntectonic leucogranite outcropping in the vicinity of the Rubian deposit (Fig. 1a,b) has a crystallisation age of $313 \pm 2$ Ma (Fernández-Suarez et al. 2000). Mafic-intermediate dykes were emplaced at c. 295-290 Ma and intruded spatially associated syntectonic granitoids during the posttectonic magmatic event (Fernández-Suarez et al. 2000).

Post-tectonic late-Variscan ( 295-285 Ma) magmatism was accompanied by regional high heat flow and hot fluid circulation that have been linked to orocline-triggered lithospheric delamination throughout the Western European Variscan belt (Gutierrez-Alonso et al. 2004).
The currently mined Rubian magnesite deposit is hosted within a hundred-metre-thick carbonate/siliciclastic metasedimentary sequence of the Cándana Limestone Formation (Fig. 1b). In the study area, the carbonates of the Cándana Limestone Formation can be followed laterally for several tens of kilometres (Fig. 1b), thickening from $14 \mathrm{~m}$ in the west of Rubian to about $70 \mathrm{~m}$ in the easternmost part of the area (Fig. 1b). The deposit comprises upper (20-m thickness) and lower (17-m thickness) lens-shaped ore bodies separated by $55 \mathrm{~m}$ of slates and micaceous schists (Fig. 2). The ore bodies consist of alternating centimetre- to decametre-scale subhorizontal beds of alternating white- and cream-coloured sparry magnesite, with some horizons consisting of blackcoloured subhedral magnesite; stylolite planes are present in the magnesite beds. The lower is the main magnesite ore body (Capa Principal; Bustillo and López-Jimeno 1997) and constitutes a package of magnesite beds, with dolomite-rich intercalations, which are mainly concentrated at the top and bottom of the ore body (Doval et al. 1977). In the upper ore body (Capas de Pondais), the sparry magnesite beds are thinner (centimetre scale mainly) and occur between slate beds, with a total thickness of up to 

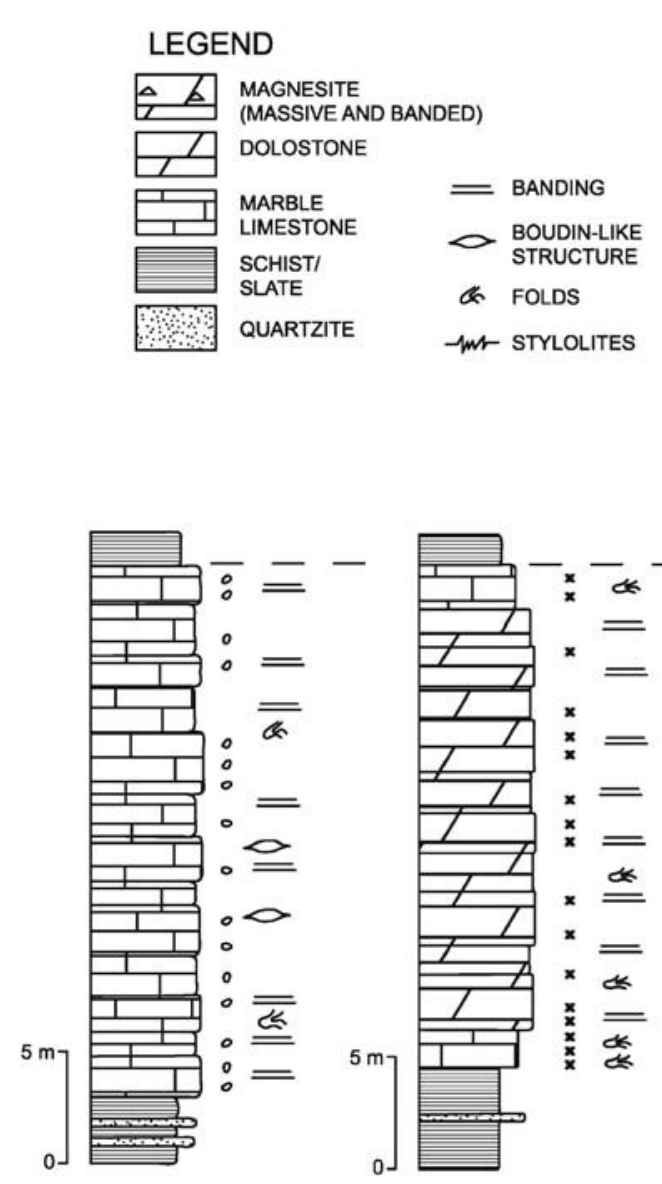

- MAO SAMPLES

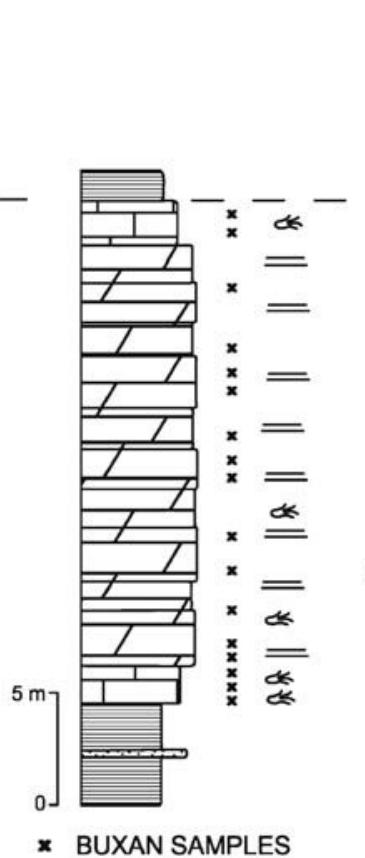

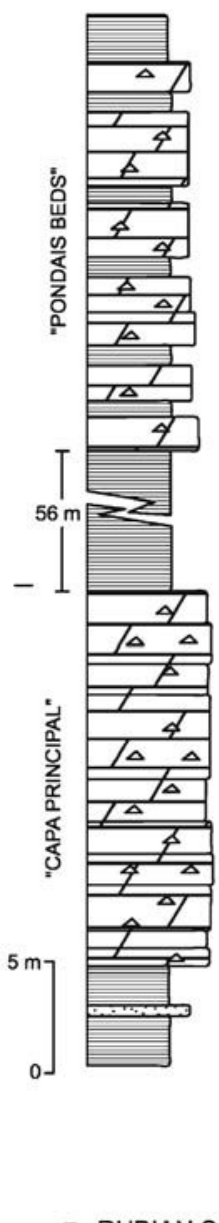

RUBIAN SAMPLES

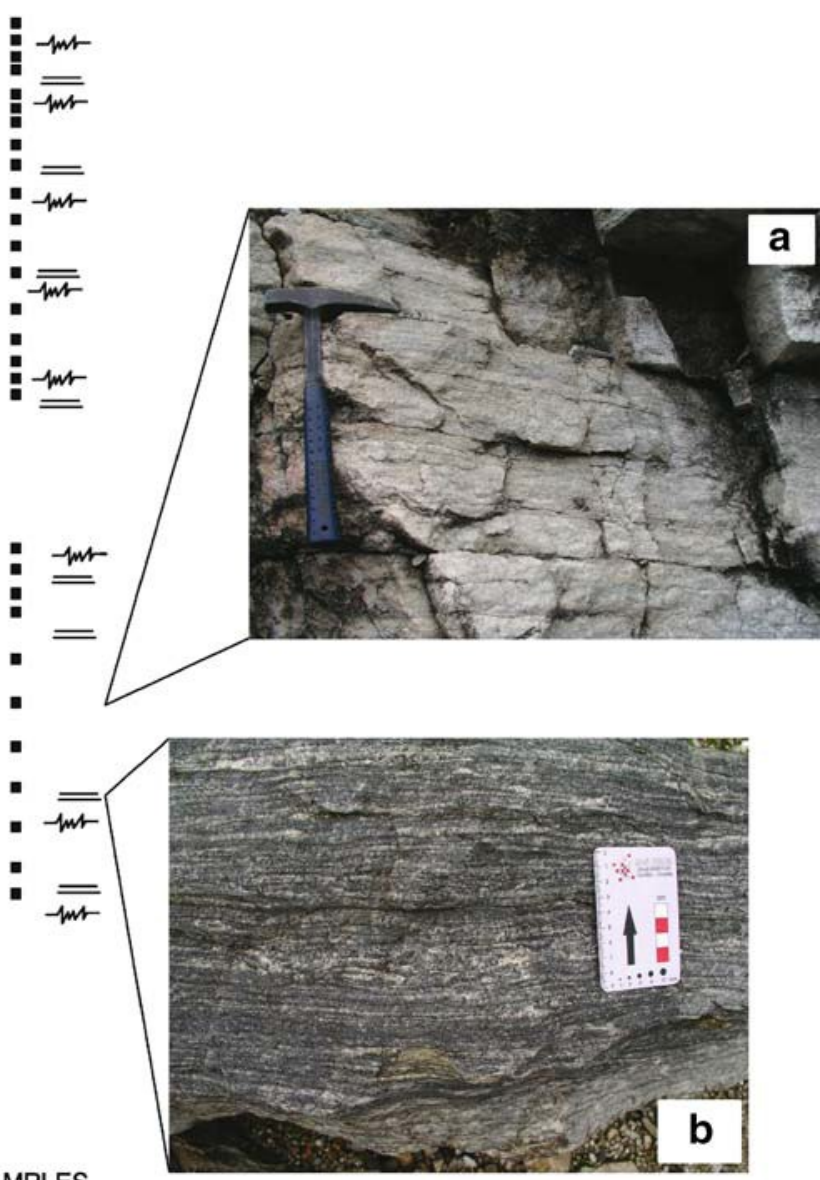

the magnesite deposits. a Close-up view of coarse-grained magnesite. b Close-up view of banded magnesite displaying thin lamination and local glitters of sparry magnesite crystals
Fig. 2 Lithostratigraphic logs of the Rubian, Buxan and Mao sections. Stratigraphic correlation at the top of the carbonate lithosomes is based on fieldwork and mapping. Outcrop views from

\section{Materials and methods}

$20 \mathrm{~m}$ (Fig. 2). In the mine, the successions are cut by up to 1-m-thick undeformed dolerite dykes. From west to east, a transition in the carbonates exists (Guillou 1970; Martínez Catalán and Pablo 1978). The magnesite rocks thicken eastwards and pass into a $\sim 21$-m-thick carbonate succession consisting mainly of thin dolostone beds (Buxan section) (Fig. 2); these are underlain by slates and the contact is marked by locally folded, centimetre-thick, dark dolomite with minor calcite beds. Overlying the thinly bedded dolostone is a package of thick dolostone beds showing metamorphic banding and local shear planes with associated folds. This results in a misleading horizontally to cross-stratified sedimentary-bedded appearance of the dolostone body. The dolostone passes eastwards to an up to 25-m-thick monotonous succession of laminated to banded, dark-greyish marble (Fig. 2). Boudin-like nodules and folds related to shear planes are locally observed in the banded marble succession. This lateral facies change conforms to a lithological zonation that has been suggested (Guillou 1970) as representative of an initial carbonate ramp depositional environment.
A total of 65 samples (55 carbonate, 10 slate and schist) were collected from three selected sections of the Cándana Limestone Formation, namely, Rubian, Buxan and Mao (see Fig. 2 for location), representing the transition from magnesite rock, through dolostone to marble. The Rubian section comprises mainly magnesite beds (samples labelled SP) with thin dolomite-rich intercalations and the samples are from borehole cores. The Buxan section comprises dolostone rocks (samples labelled BUX), whereas the Mao section consists of calcitic marble (samples labelled MAO).

X-ray diffraction (XRD) served to determine the bulk mineral composition in powdered carbonate, schist and slate samples. The powdered samples were scanned from 2 to $65^{\circ} 2 \theta$ using $\mathrm{Cu}-\mathrm{Ka}$ radiation with a scanning speed of $1 \%$ min in a Philips X-ray diffraction equipment. A quantitative estimation of relative percentages of carbonate minerals from whole-rock samples was made by measuring the peak areas, and the percentages were calculated by using the intensity factors method (Schultz 1964). According to this analytical procedure, the Rubian samples 
were characterised by a magnesite content greater than $95 \%$ of the bulk sample. For the study of phyllosilicate minerals, XRD analyses were performed on the $<2-\mu \mathrm{m}$ fraction obtained by differential settling from an aqueous suspension. Three types of clay fractions were prepared: air dried, heated to $550^{\circ} \mathrm{C}$ for $3 \mathrm{~h}$ and treated with ethyleneglycol. Mineral identification and quantification was done according to Schultz (1964).

All samples were examined using standard optical microscopy. Alizarin red S staining of thin sections was used to differentiate calcite from other carbonate minerals. No specific staining methods were used to identify magnesite from dolomite in thin section.

In addition to secondary electron and back-scattered electron (BSE) images, quantitative analyses of magnesite from five Rubian samples, dolomite from two Buxan samples and calcite from three Mao samples were obtained using a JEOL JSM-5600 electron microprobe, equipped with an energy dispersive X-ray micro analyser (EDS), operated at $10 \mathrm{kV}$ accelerating voltage with a beam current of $20 \mathrm{nA}$ and a beam size of $2 \mu \mathrm{m}$ at the Faculty of Geology and Geoenvironment, National and Kapodistrian, University of Athens.

Oxygen and carbon stable isotope measurements were carried out in the Stable Isotope Laboratory of the University of Salamanca, Spain. There were 8 wholerock samples of Mao calcite, 8 samples of whole-rock dolostone from Buxan, 7 samples of magnesite whole-rock from Rubian, and 27 samples of nearly pure magnesite (Rubian) ground to pass through a 100-mesh sieve; the 250-mesh fraction was saved for analysis of both oxygen and carbon isotopes. The fractionated extraction of $\mathrm{CO}_{2}$ from carbonates for isotope analysis followed standard techniques (McCrea 1950; Craig 1957). For isotope analysis, calcite and dolomite were reacted with phosphoric acid at $25^{\circ} \mathrm{C}$ and magnesite at $50^{\circ} \mathrm{C}$. We used phosphoric acid fractionation factors of 1.01025 for calcite (Friedman and O'Neil 1977), 1.01090 for dolomite (Rosenbaum and Sheppard 1986) and 1.01160 for magnesite (Perry and Tan 1972). A sequential extraction technique was applied for mixed dolomite-magnesite samples: the gas evolved in the first $3 \mathrm{~h}$ was attributed to calcite; the gas evolved between 3 and $72 \mathrm{~h}$ was attributed to dolomite, whereas for magnesite the time for analysis of the gas evolved lasted about 11 days. All samples were prepared and analysed at least in duplicate. The analytical precision is generally $\pm 0.10 \%$ o for carbon and $\pm 0.15 \%$ o for oxygen. The oxygen values were initially reported in $\delta$ permil relative to standard mean ocean water (SMOW) whereas carbon values are reported in $\delta$ permil relative to PDB. The dolomite-water and magnesite-water fractionation factors for oxygen have been taken from Zheng (1999); the latter factors have been preferred to that given by Mathews and Katz (1977) for dolomite ( $T$ : $252-292^{\circ} \mathrm{C}$ ) and Aharon (1988) for magnesite ( $T$ : $0-200^{\circ} \mathrm{C}$ ) because they are calculated over a larger temperature range $\left(0-1,200^{\circ} \mathrm{C}\right)$. For carbon, the dolomite$\mathrm{CO}_{2}$ fractionation factor of Ohmoto and Rye (1979) was based on the dolomite-calcite fractionation factor given by Sheppard and Schwarz (1970). The fractionation factor between magnesite and $\mathrm{CO}_{2}$ has been approximated to the dolomite- $\mathrm{CO}_{2}$ fractionation factor (Aharon 1988; Lugli et al. 2002).

Thirteen (13) carbonate samples (three calcitic marble, five dolostone and five magnesite) were selected for radiogenic ${ }^{87} \mathrm{Sr} /{ }^{86} \mathrm{Sr}$ isotope analysis. The strontium measurements were made at the Centre of Geochronology and Isotope Geochemistry of the University Complutense of Madrid using a VG TIMS mass spectrometer. The samples were dissolved in $2.5 \mathrm{~N} \mathrm{HCl}$. The solution was separated from any undissolved residue by centrifuging and then evaporated to dryness and the residue was redissolved in $2.5 \mathrm{~N} \mathrm{HCl}$. The measured $\mathrm{Sr}$ isotope ratios were corrected for mass fractionation relative to ${ }^{87} \mathrm{Sr} /{ }^{86} \mathrm{Sr}=0.1194$. The mean value obtained for the international standard NBS 987 was $0.710244 \pm 0.00002(2 \sigma)$ $(n=11)$. The analytical precision for ${ }^{87} \mathrm{Sr} /{ }^{86} \mathrm{Sr}$ analysis is $0.01 \%$

Fourteen (14) carbonate samples (five Mao calcitic marble, five Buxan dolostone and four Rubian magnesite) were selected and analysed for trace and rare earth elements. Analyses were made by inductively coupled plasma mass spectrometry in the Chemistry Laboratory of the University of Granada, Spain. The powdered samples (100 mg) were digested by $\mathrm{HNO}_{3}+\mathrm{HF}$ in teflon-lined vessels at $\sim 180^{\circ} \mathrm{C}$ and $\sim 200$ psi for $30 \mathrm{~min}$ and evaporated to dryness, and the residue was dissolved in $100 \mathrm{ml}$ of 4 vol.\% $\mathrm{HNO}_{3}$. Measurements were carried out in triplicate with a PE SCIEX ELAN-5000 spectrometer using Rh as internal standard. Precision was better than $\pm 2 \%$.

Fluid inclusion data were obtained on seven Rubian magnesite samples including both massive and banded specimens. For microthermometry, the samples were prepared as free-standing, 100 - to $200-\mu \mathrm{m}$-thick doubly polished wafers. Microthermometric measurements were carried out at the Economic Geology and Geochemistry Department of the National and Kapodistrian University of Athens, Greece using a LINKAM TMSG600 heatingfreezing stage. The stage was calibrated with natural carbon-dioxide-bearing fluid inclusions of known composition and commercially available standards. The estimated analytical error is $\pm 0.2^{\circ} \mathrm{C}$ for low $\left(<50^{\circ} \mathrm{C}\right)$ and $\pm 2^{\circ} \mathrm{C}$ for higher $\left(>75^{\circ} \mathrm{C}\right)$ temperatures.

\section{Petrography and structure of carbonates}

\section{Calcitic marble}

Mineralogical and XRD data indicate that calcite is the dominant mineral in the Mao marble samples with minor dolomite and quartz. Calcite displays three main textural types: (1) inhomogeneous aggregates of calcite crystals, ranging from $150 \mu \mathrm{m}$ to up to $4 \mathrm{~mm}$ in diameter; the calcite crystals show extensive twinning and cleavage planes leading to a granoblastic fabric with common crystal-face junctions at $120^{\circ}$; bioclast ghosts (crinoids?, bivalves?) are locally recognised together with xenotopic dolomite crystals; (2) banded marble calcite where fine-grained 
(c. $70 \mu \mathrm{m}$ ) up to $650-\mu \mathrm{m}$-thick dolomite-rich layers are found within aggregates of coarse $(100-300 \mu \mathrm{m})$ calcite crystals - the calcite crystals exhibit strong twinning and serrated intercrystalline boundaries (Fig. 3e) and (3) variably sized aggregates of calcite crystals showing features similar to a protomylonite. The coarser calcite crystals, averaging $2 \mathrm{~mm}$ in diameter, are strongly twinned and define foliation in the rock whereas the fine-grained (average $100 \mu \mathrm{m}$ ) crystals exhibit a granoblastic texture with common junctions at $120^{\circ}$. Irrespective of calcite type, non-carbonate aggregates, mineral inclusions comprise mainly muscovite (sericite), quartz (both grains and


Fig. 3 Petrographic features of carbonates. a Photomicrograph of banded magnesite with alternating carbonate bands marked by difference in crystal size and shape; see also separation by dark stylolitic joints. b Photomicrograph of massive magnesite showing well-defined equigranular texture with common curved xenotopic magnesite crystals; note the presence of quartz and apatite as

inclusions in the magnesite. c SEM image of dolomite relics (white) within magnesite (dark grey). d Photomicrograph of banded dolomite exhibiting alternation of fine and coarse crystalline dolomite bands. e Photomicrograph of banded calcite showing granoblastic fabric composed of twinned calcite crystals with fine dolomite and silicate (quartz + muscovite) inserts 
"ribbons"), apatite, zircon, pyrite and iron oxides. Thorogummite $\left(\mathrm{ThO}_{2}\right.$ : 16.04-28.93, $\mathrm{SiO}_{2}$ : 3.46-5.39, $\mathrm{P}_{2} \mathrm{O}_{5}$ : 1.73-5.23, $\mathrm{CaO}: 32.66-44.46$ ) has been identified as small grains related to apatite.

\section{Dolostone}

The dolostone consists mainly of pale brown or grey crystals of dolomite, in some cases accompanied by white dolomite. The textures of these rocks were described according to Sibley and Gregg (1987). Two main types were identified: massive and banded dolostone. Massive dolostone is composed of tightly packed unimodal to polymodal idiotopic to sub-idiotopic mosaic of fine- to medium-grained $(0.15-0.35 \mathrm{~mm})$ dolomite crystals. Aggrading neomorphism and poikilotopic and micrographic textures have also been recognised. Banded dolostone consists of alternating layers of coarse-grained $(500 \mu \mathrm{m})$ idiotopic dolomite crystals and fine-grained $(<150 \mu \mathrm{m})$ sub-idiotopic to xenotopic dolomite crystals (Fig. 3d). A pseudo-banding structure is locally present where massive dolostone layers exhibit stylolites; in this case, no variation in dolomite crystal size is observed. Moreover, wavy stylolites marked by black carbonaceous material occur commonly in the banded dolostone.

Muscovite (sericite), biotite, corrensite group minerals, quartz, Mg-chlorite, talc, pyrite and apatite are also present as inclusions within the dolomite grains or filling intercrystalline spaces. The crystal sizes for euhedral quartz range between 40 and $200 \mu \mathrm{m}$, irregular patches of sericite flakes range in size from 100 to $500 \mu \mathrm{m}$, apatite occurs as minute $(<40 \mu \mathrm{m})$ euhedral isolated crystals and pyrite occurs locally as millimetre-sized octahedra.

\section{Magnesite}

Two types of magnesite have been distinguished — banded and sparry.The banded structure is due to the rhythmic alternation of coarse-grained ( $>2 \mathrm{~mm}$ ) sparry and finegrained $(<100 \mu \mathrm{m})$ mosaic magnesite layers with stylolites or bedding planes separating two successive sparry and mosaic magnesite layers (Fig. 3a). The layers are mostly wavy and roughly parallel to bedding and characterised by the bipolarity of mosaic magnesite. The sparry magnesite layers consist mainly of lens-shaped and/or equant crystals which often have grown perpendicular to and away from stylolite planes - producing a characteristic banded structure where stylolites are closely spaced. In addition, they also show pinolites, radial aggregates, antipolar crystals and poikilotopic textures. Stylolites are mostly sub-parallel to bedding and mainly coincide with lamination and bedding planes. Two types are evident: type 1 stylolites contain only muscovite and quartz, are devoid of insoluble black-coloured carbonaceous and clay material and are comparatively thicker; type 2 stylolites consist exclusively of chlorite, black-coloured carbonaceous material, pyrite and iron oxides and are thinner. In both cases, stylolite spacings range between 3 and $15 \mathrm{~mm}$. The characteristic "black and white" banded structure (Fig. 2) is due to a combination of magnesite crystal colour, texture and stylolite spacing. Typically "black" bands are arranged on both sides of closely spaced type 2 stylolites and consist mainly of mosaic magnesite "white" bands occuring along with type 1 stylolites and are mostly associated with sparry magnesite.

Sparry magnesite consists of a mosaic of coarse (>1.5 mm) interlocked nonplanar (xenotopic) crystals showing micrographic and poikilotopic textures (Fig. 3b). Anhedral and closely packed crystals with irregular, even serrated or curved intercrystalline boundaries are the most common. Aggregates of very fine-grained $(<5 \mu \mathrm{m})$ anhedral magnesite are locally included in coarse-grained euhedral magnesite crystals (Fig. 4a).

XRD analyses reveal that most of the magnesite samples contain variable amounts of dolomite; back-scattered electron images of these samples showed that these occur as microinclusions $(<50 \mu \mathrm{m})$ within magnesite (Fig. 3c). Furthemore, euhedral dolomite crystal assemblages were found replacing magnesite along crystal boundaries,
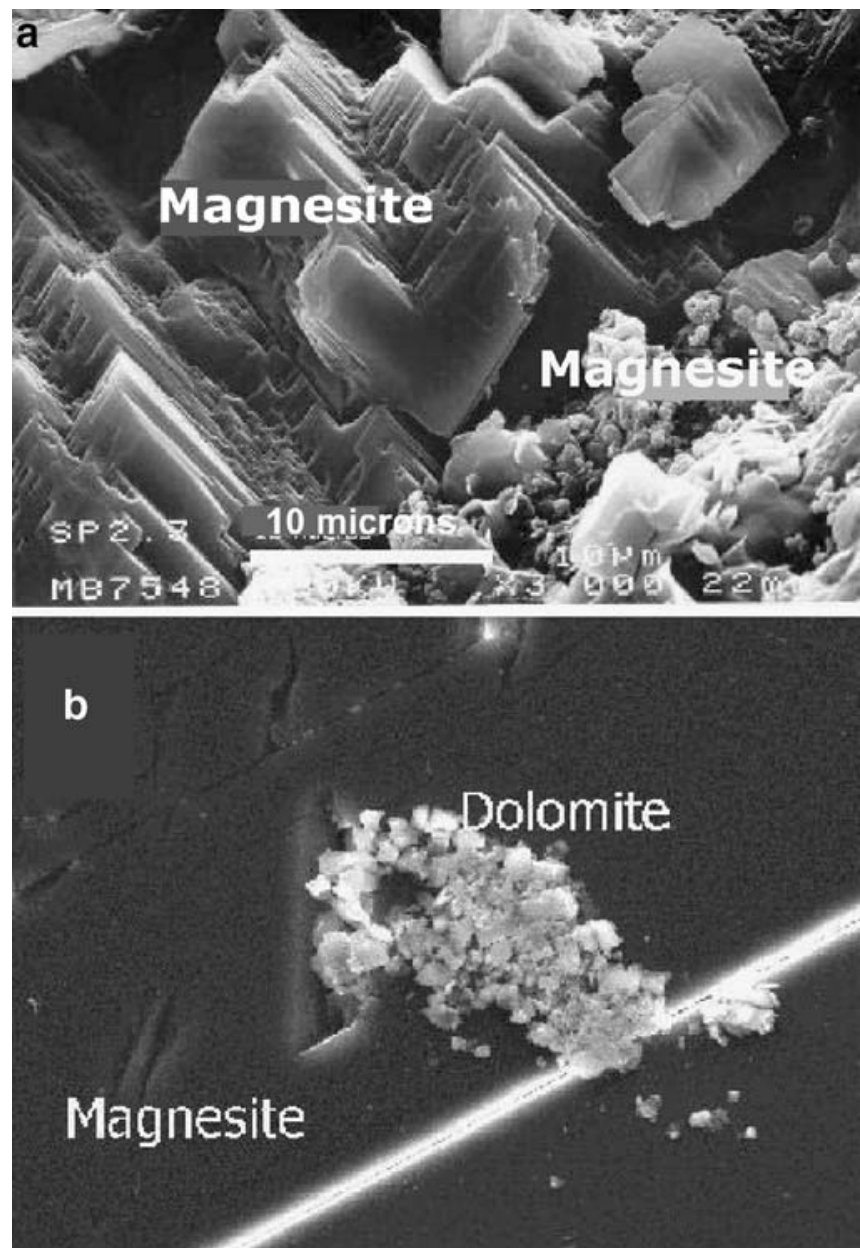

Fig. 4 a SEM image of large spar magnesite crystals showing local aggregates of fine magnesite crystals. b Back-scattered electron image showing small euhedral dolomite crystals replacing large sparry magnesite crystals (scale bar as in a) 
cleavage planes and microfractures (Fig. 4b) - this feature has also been observed in Eugui as well as in Rum Jungle and Veitsch magnesite deposits (Lugli et al. 2000; Aharon 1988). Petrographic and XRD data indicate that both magnesite types contain quartz, muscovite (sericite), biotite, corrensite group minerals, Mg-chlorite (clinochlore) and minor talc, with apatite and pyrite and subordinate rutile as accessory minerals in variable amounts that may make up to $10 \%$ by volume. Quartz occurs either as isolated inclusions within magnesite, in intercrystalline spaces or in microfractures and/or cavities. The average crystal size is $150-200 \mu \mathrm{m}$ and may reach up to $1 \mathrm{~mm}$. Mg-chlorite and Ba-rich muscovite (Table 1) flaky assemblages are usually associated with quartz filling intercrystalline spaces. Scattered minute grains of $\mathrm{Cl}$ apatite prisms and pyrite octahedra also occur. The representative chemical analyses of the non-carbonate minerals are shown in Tables 1 and 2.

Marble and dolostone from Mao and Buxan sections, respectively, show evidence of Variscan deformation in the form of extensional shearing fold-related deformation, whereas the Rubian dolomite and magnesite outcrop and drillcore samples show no evidence of such tectonic disturbance; in addition, Rubian carbonates are characterised by absence of twins or other microscopic evidence of crystal deformation. Furthermore, bedding parallel stylolites did affect neither Rubian dolomite nor magnesite, suggesting that the carbonates postdate the development of stylolites. The above observations suggest that the dolomitisation and magnesite formation at Rubian are postorogenic as they postdate the main phases of Variscan deformation in the area.

\section{Mica-schists and slates}

Schistose fine-grained siliciclastic metasedimentary rocks interbedded with the carbonate rocks in the studied sections (Fig. 2) comprise mainly micaceous minerals and quartz. Two main types of schistose rocks are seen: (1) quartzites which are characterised by granolepidoblastic to lepidoblastic texture and consist of quartz with muscovite and biotite, as well as illite and traces of chlorite and albite and (2) chlorite-schists which contain biotite and/or garnet porphyroblasts within a schistose matrix of chlorite, quartz and muscovite. Accessory minerals found in both types include apatite, green amphibole (actinolite-tremolite) and pyrite. Slate occurs as a subordinate rock showing a welldefined foliation and finer-grained sheet minerals arranged in a lepidoblastic texture containing coarser biotite porphyroblasts.

\section{Dyke rocks}

They constitute dark-coloured medium-grained rocks with evidence of hydrothermal alteration. Mineralogical composition and microscopic textures classify them as dolerite; they exhibit ophitic to sub-ophitic texture consisting of Ca-

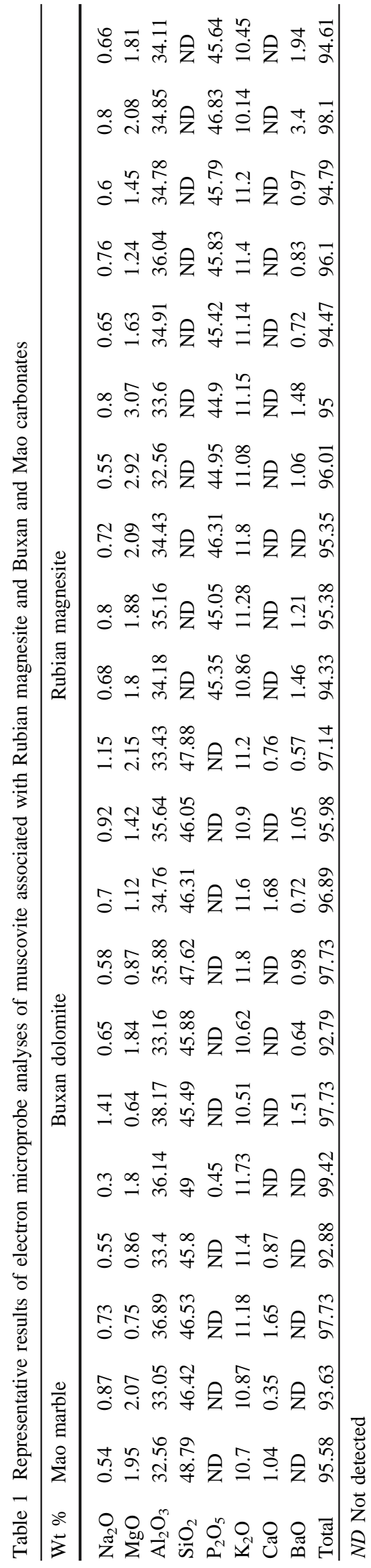


Table 2 Representative results of electron microprobe analyses of Mg-chlorite associated with Rubian magnesite

\begin{tabular}{|c|c|c|c|c|c|c|c|c|}
\hline \multirow{2}{*}{$\begin{array}{l}\text { Wt \% } \\
\mathrm{MgO}\end{array}$} & \multicolumn{8}{|c|}{ Rubian Magnesite } \\
\hline & 31.88 & 32.66 & 31.46 & 32.36 & 31.18 & 32.26 & 31.76 & 32.68 \\
\hline $\mathrm{Al}_{2} \mathrm{O}_{3}$ & 18.45 & 17.66 & 15.31 & 13.87 & 17.85 & 17.98 & 16.85 & 15.5 \\
\hline $\mathrm{SiO}_{2}$ & 38.24 & 37.58 & 38.96 & 39.06 & 39.1 & 38.1 & 38.89 & 38.99 \\
\hline $\mathrm{CaO}$ & 0.56 & 0.6 & ND & ND & 0.59 & 0.57 & ND & ND \\
\hline $\mathrm{Fe}_{2} \mathrm{O}_{3}$ & 0.64 & 0.65 & 0.9 & 0.88 & 0.73 & 0.69 & 0.92 & 0.89 \\
\hline Total & 89.77 & 89.15 & 86.63 & 86.79 & 89.92 & 89.6 & 88.42 & 88.06 \\
\hline
\end{tabular}

ND Not detected

rich plagioclase laths and highly altered $\mathrm{Fe}-\mathrm{Mg}$ minerals. Alteration includes mainly Mg-chlorite, green amphibole and iron oxides. Locally carbonate aggregates either isolated or infilling microcracks were observed.

\section{Geochemistry}

Major elements

The electron microprobe analyses of selected major elements of the Rubian and Buxan carbonates are listed in Table 3. No significant variation in the composition of magnesite has been found. Small amounts of $\mathrm{CaO}$ between nil and $0.44 \mathrm{wt} \%$ indicate residual micro inclusions of dolomite in magnesite; magnesite contains 1.13-1.43 wt\% $\mathrm{FeO}$; dolomite micro inclusions in magnesite as well as dolomite from Buxan dolostone have lower $\mathrm{FeO}$ contents $0.29-0.52$ and $0.0-0.74 \mathrm{wt} \%$, respectively, compared to the host magnesite (Table 3).

\section{Trace elements}

The trace element contents of the studied samples are listed in Table 4. According to the correlations between all trace elements, they can be subdivided into different groups: (1) $\mathrm{Rb}, \mathrm{Cs}, \mathrm{Ga}, \mathrm{Zr}, \mathrm{U}, \mathrm{V}$ and Sc have similar geochemical

Table 3 Statistical data of magnesite and dolomite electron microprobe analyses (wt \%)

\begin{tabular}{llll}
\hline & $\mathrm{MgO}$ & $\mathrm{CaO}$ & $\mathrm{FeO}$ \\
\hline Magnesite $(n=36)$ & & & \\
Mean & 47.8 & 0.41 & 1.16 \\
Median & 48.28 & 0.39 & 1.04 \\
Standard deviation & 1.38 & 0.25 & 0.63 \\
Minimum & 43.89 & 0.05 & 0.57 \\
Maximum & 49.26 & 0.87 & 3.35 \\
Dolomite relics in magnesite $(n=11)$ & & & \\
$\quad$ Mean & 22.66 & 26.6 & 0.42 \\
Median & 23.43 & 26.01 & 0.44 \\
Standard deviation & 1.83 & 1.56 & 0.11 \\
Minimum & 19.66 & 24.99 & 0.29 \\
Maximum & 24.39 & 29.8 & 0.67 \\
\hline
\end{tabular}

behaviour in all samples analysed as they show mutual positive correlation. These elements are interpreted to reflect the aluminosilicate fraction (muscovite and chlorite) of the samples. Barium shows positive correlation with all the above elements (correlation coefficient between 0.70 and 0.90); this combined with the lack of barite and the elevated $\mathrm{Ba}$ contents of muscovite (Table 1 ) reflects the $\mathrm{Ba}$ presence in muscovite; (2) $\mathrm{Cr}$, $\mathrm{Ni}$ and $\mathrm{Li}$ show positive mutual correlations but do not correlate with any other elements. In addition, Rubian magnesite has higher $\mathrm{Cr}, \mathrm{Ni}$ and $\mathrm{Li}$ contents compared to Buxan dolomite and Mao marble (Table 4), suggesting that they have been introduced by the magnesite-forming fluids. It should be noted that "black" bands in replacive magnesite from Eugui, the other sparry magnesite deposit of Spain, show the highest $\mathrm{Cr}$, Ni and Co contents (Lugli et al. 2000).

The strontium contents of Rubian magnesite are generally lower than those of Buxan dolomite and Mao marble, because $\mathrm{Sr}$ cannot enter the magnesite lattice (Möller 1989). The relatively high Sr concentrations in samples SP4-1 and SP4-10 probably reflect dolomite inclusions. The high $\mathrm{Cr}$ and $\mathrm{Ni}$ may have derived from altered dolerite. Similar high $\mathrm{Cr}$ and $\mathrm{Ni}$ concentrations have been reported from sedimentary magnesite that has formed above an ultrabasic substrate (Stamatakis 1995).

\section{Rare earth elements}

The abundance of rare earth elements in Rubian magnesite, Buxan dolostone and Mao calcite is shown in Table 5. No statistically meaningful correlation was found between REE contents and other trace elements (see Table 4).

All analysed Rubian sparry magnesite contain detectable amounts of light rare earth elements (LREE) (Table 5). The total REE contents (absolute values: 2.48-7.57, mean: 4.29; Table 5) are very similar to those of Buxan dolostone (absolute values: 4.21-8.02; mean: 6.32 Table 5), but magnesite is depleted in LREEs relative to the dolostone, and heavy rare earth elements show comparable concentrations (Table 5). However, the chondrite-normalised REE patterns (Fig. 5) of magnesite are quite flat and lack any characteristic anomaly indicative of marine environment (i.e. negative Ce anomaly - Möller 1989; Bau and Moller 1992) or fluid equilibration with feldspar before magnesite formation (positive Eu anomaly - Möller 1989). Magne- 
Table 4 Trace element contents (ppm)

\begin{tabular}{|c|c|c|c|c|c|c|c|c|c|c|c|c|c|c|c|}
\hline Sample & $\mathrm{Sr}$ & $\mathrm{Ba}$ & $\mathrm{Rb}$ & Cs & Sc & V & $\mathrm{Li}$ & $\mathrm{Cr}$ & Co & $\mathrm{Ni}$ & $\mathrm{Ga}$ & $\mathrm{Y}$ & $\mathrm{Zr}$ & $\mathrm{Pb}$ & $\mathrm{U}$ \\
\hline BUX-8 & 14.63 & 20.19 & 3.39 & 0.34 & 1.94 & 2.93 & 0.97 & 7.40 & 1.04 & 7.04 & 1.42 & 2.62 & 2.45 & 0.37 & 0.07 \\
\hline BUX-13 & 14.21 & 23.79 & 4.45 & 0.38 & 0.93 & 3.81 & 1.22 & 11.26 & 1.21 & 7.25 & 1.60 & 1.68 & 3.30 & 0.00 & 0.09 \\
\hline BUX-6 & 21.02 & 24.07 & 2.75 & 0.21 & 1.44 & 4.65 & 1.14 & 6.85 & 1.03 & 7.22 & 1.48 & 2.97 & 3.20 & 14.64 & 0.16 \\
\hline MAO-3 & 261.62 & 18.95 & 8.29 & 0.51 & 1.37 & 4.09 & 3.18 & 8.80 & 1.48 & 14.36 & 1.74 & 1.85 & 4.32 & 2.25 & 0.21 \\
\hline MAO-12 & 270.74 & 20.79 & 7.22 & 0.33 & 1.45 & 7.65 & 2.22 & 13.66 & 1.24 & 15.23 & 1.80 & 1.50 & 4.43 & 4.47 & 0.53 \\
\hline MAO-14 & 180.56 & 41.00 & 14.93 & 0.80 & 2.45 & 9.04 & 8.91 & 18.91 & 2.08 & 15.49 & 2.99 & 3.52 & 9.88 & 3.08 & 1.45 \\
\hline MAO-4 & 269.77 & 32.36 & 12.03 & 0.83 & 1.73 & 6.71 & 4.83 & 14.71 & 1.61 & 15.21 & 2.32 & 2.92 & 6.86 & 2.77 & 0.29 \\
\hline SP4-1 & 152.93 & 114.53 & 13.65 & 0.90 & 2.98 & 57.09 & 13.21 & 65.65 & 2.34 & 287.70 & 4.08 & 36.32 & 14.31 & 1.04 & 19.49 \\
\hline SP4-4 & 0.48 & 1.76 & 0.28 & 0.01 & 0.03 & 0.62 & 3.71 & 24.94 & 0.58 & 147.81 & 0.87 & 1.56 & 0.45 & 0.00 & 0.19 \\
\hline
\end{tabular}

site is distinct from Mao calcite both in terms of REE concentrations and chondrite normalised patterns, indicating that these rocks were formed in different environments (Table 5; Fig. 5).

\section{Fluid inclusions}

Petrography and classification of fluid inclusions

Fluid inclusions were observed and measured only in Rubian massive and banded magnesite samples. Buxan dolomite and Mao calcite were examined for fluid inclusions, but their small size $(<5 \mu \mathrm{m})$ precluded using them for microthermometric work.

Both textural types of magnesite contain two types of fluid inclusions: (1) very common simple aqueous twophase liquid-vapour ( $\mathrm{L}-\mathrm{V})$ inclusions and 2 ) rare aqueous three- or multi-phase liquid-vapour-solid(s) $(\mathrm{L}-\mathrm{V} \pm \mathrm{S})$ inclusions, which contain one or two additional unidentified solid(s) with sizes ranging from 10 to $>50+\mu \mathrm{m}$. The solid phases may be equant or sub-rounded, transparent prismatic (carbonate?) and, in rare cases, opaque with metallic lustre (sulphides?). Based on non-uniformity in the volume ratios of the solid phase(s), they are not considered daughter minerals but accidentally trapped solids. Liquidrich $(<30 \%$ vapour) aqueous inclusions in magnesite comprise $99 \%$ of the fluid inclusion population. Very rare vapour-rich $(>50 \%)$ inclusions were observed but these inclusions may be due to necking or natural decrepitation or leakage, as they did not homogenise even when heated to $>350^{\circ} \mathrm{C}$. In addition, solid phases do not dissolve when heated to these temperatures.

Care was taken so that all measured fluid inclusions are primary in origin (Roedder 1984). Obvious secondary inclusions healing transgranular fractures were avoided. It

Table 5 Rare earth element contents (ppm)

\begin{tabular}{llllllllllllllll}
\hline Sample & Mineral & $\mathrm{La}$ & $\mathrm{Ce}$ & $\mathrm{Pr}$ & $\mathrm{Nd}$ & $\mathrm{Sm}$ & $\mathrm{Eu}$ & $\mathrm{Gd}$ & $\mathrm{Tb}$ & $\mathrm{Dy}$ & $\mathrm{Ho}$ & $\mathrm{Er}$ & $\mathrm{Tm}$ & $\mathrm{Yb}$ & $\mathrm{Lu}$ \\
\hline BUX-17 & Dolomite & 0.489 & 1.489 & 0.230 & 0.960 & 0.180 & 0.050 & 0.207 & 0.034 & 0.221 & 0.048 & 0.143 & 0.020 & 0.118 & 0.018 \\
BUX-8 & Dolomite & 0.742 & 2.222 & 0.340 & 1.580 & 0.480 & 0.070 & 0.384 & 0.059 & 0.433 & 0.079 & 0.227 & 0.035 & 0.230 & 0.036 \\
BUX-14 & Dolomite & 0.805 & 2.401 & 0.320 & 1.270 & 0.300 & 0.050 & 0.259 & 0.048 & 0.319 & 0.074 & 0.215 & 0.031 & 0.194 & 0.035 \\
BUX-13 & Dolomite & 0.898 & 2.235 & 0.310 & 1.220 & 0.320 & 0.080 & 0.222 & 0.041 & 0.292 & 0.059 & 0.173 & 0.027 & 0.158 & 0.030 \\
BUX-6 & Dolomite & 1.274 & 2.577 & 0.410 & 1.820 & 0.420 & 0.120 & 0.402 & 0.057 & 0.409 & 0.084 & 0.210 & 0.031 & 0.181 & 0.024 \\
MAO-3 & Calcite & 2.534 & 4.996 & 0.570 & 1.860 & 0.410 & 0.080 & 0.385 & 0.054 & 0.313 & 0.063 & 0.175 & 0.022 & 0.142 & 0.019 \\
MAO-15 & Calcite & 1.413 & 2.664 & 0.360 & 1.360 & 0.340 & 0.060 & 0.233 & 0.037 & 0.238 & 0.051 & 0.137 & 0.016 & 0.093 & 0.011 \\
MAO-12 & Calcite & 1.454 & 3.091 & 0.340 & 1.560 & 0.210 & 0.040 & 0.219 & 0.038 & 0.187 & 0.039 & 0.167 & 0.025 & 0.126 & 0.015 \\
MAO-14 & Calcite & 3.868 & 7.320 & 0.940 & 3.300 & 0.640 & 0.130 & 0.610 & 0.092 & 0.515 & 0.105 & 0.301 & 0.044 & 0.270 & 0.036 \\
MAO-4 & Calcite & 3.991 & 7.652 & 0.860 & 3.610 & 0.680 & 0.170 & 0.544 & 0.082 & 0.427 & 0.096 & 0.302 & 0.035 & 0.227 & 0.023 \\
SP4-4 & Magnesite & 0.196 & 0.564 & 0.090 & 0.620 & 0.200 & 0.060 & 0.235 & 0.044 & 0.256 & 0.040 & 0.098 & 0.012 & 0.062 & 0.008 \\
SP4-6 & Magnesite & 0.310 & 1.063 & 0.180 & 0.730 & 0.210 & 0.070 & 0.259 & 0.039 & 0.204 & 0.038 & 0.108 & 0.017 & 0.086 & 0.007 \\
SP4-7 & Magnesite & 0.446 & 1.376 & 0.170 & 0.710 & 0.210 & 0.070 & 0.207 & 0.033 & 0.211 & 0.049 & 0.144 & 0.025 & 0.130 & 0.016 \\
SP4-10 & Magnesite & 1.370 & 2.947 & 0.300 & 1.360 & 0.310 & 0.110 & 0.325 & 0.057 & 0.329 & 0.070 & 0.185 & 0.026 & 0.167 & 0.018 \\
\hline
\end{tabular}



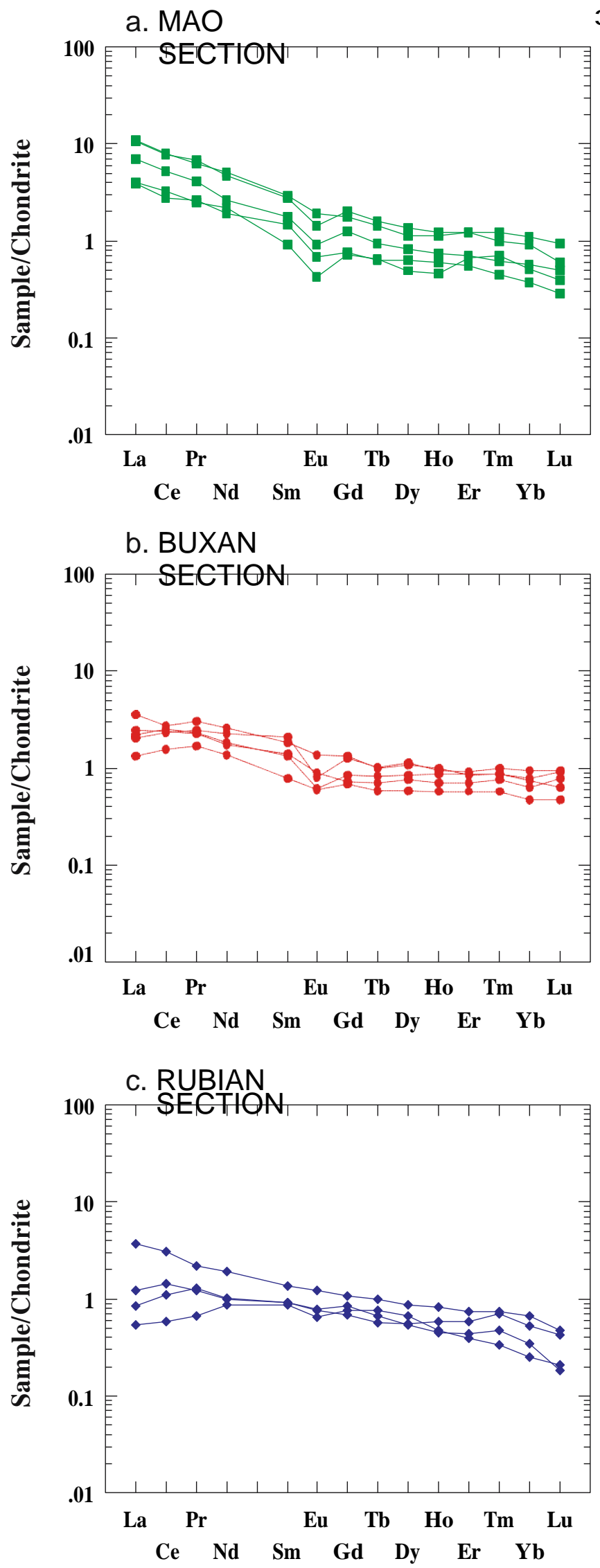

3 Fig. 5 Chondrite normalised REE patterns of Mao calcite (a), Buxan dolomite (b) and Rubian magnesite (c). Chondrite composition after Sun and McDonough (1989)

should be noted that no differences in microthermometric measurements were observed either between core- and rimbound inclusions in zoned magnesite or between massive and banded magnesite. Therefore, microthermometry data are treated collectively.

Microthermometry results and fluid inclusion composition

Fluid inclusions yielded highly variable low-temperature microthermometric measurements (Fig. 6a-c), and this variation indicates changes in bulk fluid composition during trapping. In most studied inclusions, no apparent freezing occurred even when temperature was cooled down to $-120^{\circ} \mathrm{C}$. The crystallisation of the inclusion during subsequent heating could be observed in the -70 to $-80^{\circ} \mathrm{C}$ range, evidenced by the appearance of a brownish sluggish mass. First melting $\left(T_{\mathrm{fm}}\right)$ or eutectic temperatures $\left(T_{\mathrm{e}}\right)$, demonstrated by the first appearance of liquid, were observed between $-42^{\circ}$ and $-65^{\circ} \mathrm{C}$ with a clear peak centred on $-60^{\circ} \mathrm{C}$ and two minor peaks at -56 and -52 to $-50^{\circ} \mathrm{C}$ (Fig. 6a). Hydrohalite melting was the next observed phase change and occurred in a temperature range of -30 to $-46.6^{\circ} \mathrm{C}$ with a mean of about $-38 \pm 5^{\circ} \mathrm{C}$ and a mode of $-44^{\circ} \mathrm{C}$ (Fig. $6 \mathrm{~b}$ ). Ice always melted after hydrohalite and was the last solid phase to melt. Final ice melting temperature $\left(T_{\mathrm{m}, \text { ice }}\right)$ scatter by several tens of degrees, from -1.9 to $-42.9^{\circ} \mathrm{C}$ (Fig. 6c) and possibly represent two populations, one between 0 and $-10^{\circ} \mathrm{C}$ and the other between -35 and $-45^{\circ} \mathrm{C}$. In the absence of Raman spectrometry to be combined to microthermometry for the determination of the types of dissolved salts (Bakker 2004), first melting temperatures below $-50^{\circ} \mathrm{C}$ are very difficult to interpret because they may represent very low metastable apparent eutectics due to metastable hydrate formation during rapid freezing (Davies et al. 1990). The necessarily high $\mathrm{Mg} /(\mathrm{Ca}+\mathrm{Mg})$ ratio in the fluids to account for magnesite formation and the observed low eutectics strongly suggest a fluid composition in the quaternary system $\mathrm{MgCl}_{2}-\mathrm{NaCl}-\mathrm{CaCl}_{2}-\mathrm{H}_{2} \mathrm{O}$ (Johannes 1970; Fabricius 1984). Such composition may be expected in view of the lithological context of the deposit. The system $\mathrm{MgCl}_{2}-\mathrm{NaCl}-\mathrm{CaCl}_{2}-\mathrm{H}_{2} \mathrm{O}$ is very complex and salinity calculation in such a system is not possible as no equation is available. The salinities of those inclusions with final ice melting temperature $\left(T_{\mathrm{m}, \text { ice }}\right)$ lower than $T_{\mathrm{e}}$ of the $\mathrm{H}_{2} \mathrm{O}-\mathrm{NaCl}$ system (i.e. $-21.2^{\circ} \mathrm{C}$ ) were calculated in the $\mathrm{H}_{2} \mathrm{O}-\mathrm{NaCl}$ system (Bodnar 1993) with the use of AQSO3e software from the computer package FLUIDS (Bakker 2001, 2003). For mixed Ca-Na-K-Mg chlorine solutions, the error in estimating salinity using final ice melting temperatures has been estimated to be $<5 \mathrm{wt} \% \mathrm{NaCl}$ equivalent (Clyne and Potter 1977). Salinities range from 3.3 to $16.7 \mathrm{wt} \% \mathrm{NaCl}$ equivalent. For those fluid inclusions 
a
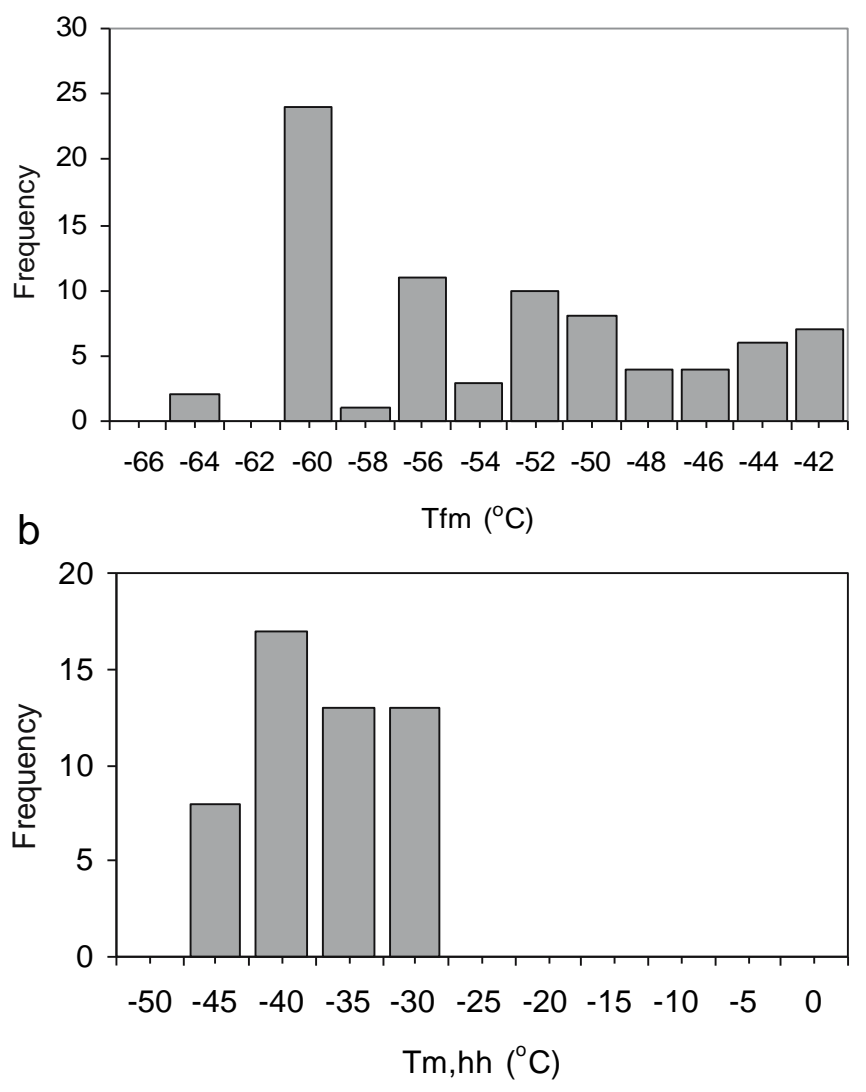

C

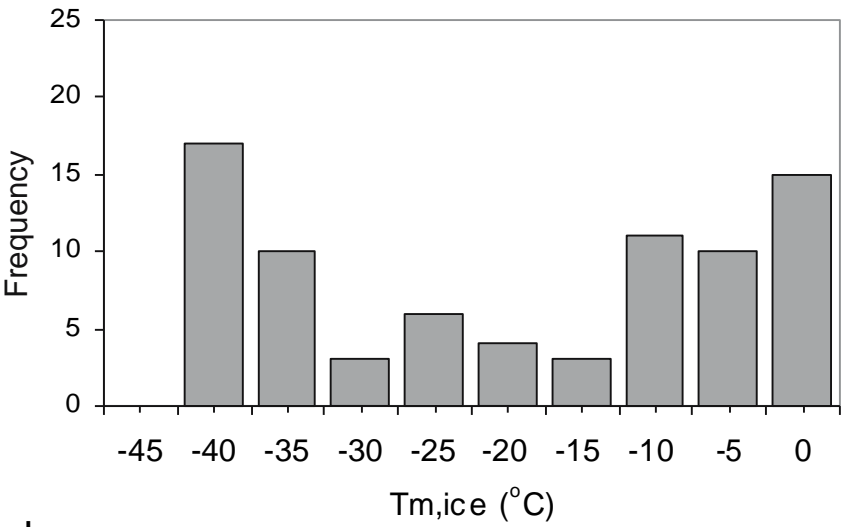

d

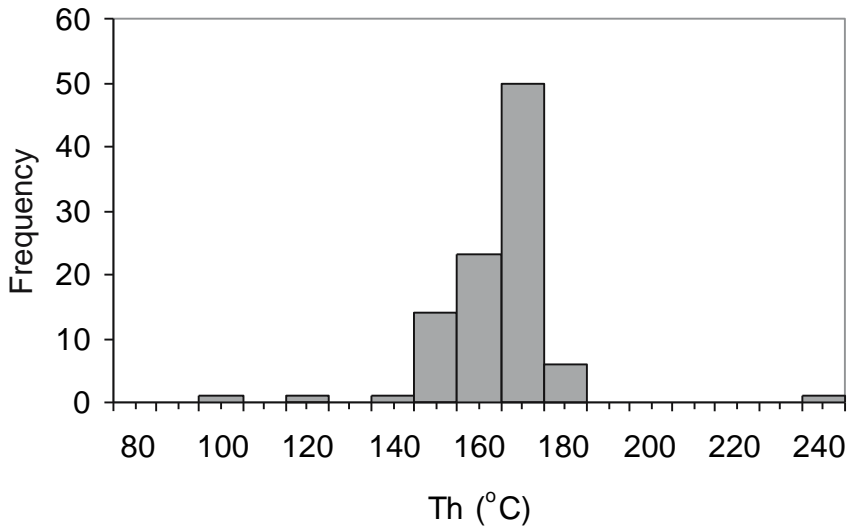

3 Fig. 6 Microthermometric measurements of two-phase fluid inclusions in magnesite $\left({ }^{\circ} \mathrm{C}\right)$. a Histogram of first melting $T_{\mathrm{fm}}$ or eutectic temperature. b Histogram of hydrohalite melting temperature $T_{\mathrm{m} \text {,hh }}$. c Histogram of final ice melting temperature $T_{\mathrm{m} \text {,ice }}$. $\mathrm{d}$ Histogram of total homogenisation temperature $T_{\mathrm{h}}$

which have final ice melting at temperatures lower than $-21.1^{\circ} \mathrm{C}$, salinities were calculated in the $\mathrm{NaCl}-\mathrm{CaCl}_{2}-$ $\mathrm{H}_{2} \mathrm{O}$ system (Oakes et al. 1990; Vanko et al. 1988) with the use of the macro programme of Naden (1996). The salinity of these fluid inclusions ranges between 22.8 and $29.5 \mathrm{wt} \%$ $\mathrm{NaCl}+\mathrm{CaCl}_{2}$ equivalent.

All studied fluid inclusions exhibited bubble-point homogenisation at temperatures from 92 to $235^{\circ} \mathrm{C}$ (Fig. 6d). However, with the exception of four homogenisation temperatures, the data fall within a relatively narrow range between 140 and $180^{\circ} \mathrm{C}$ (mean $160 \pm 13^{\circ} \mathrm{C}$, $n=97)$. In terms of combined final ice melting and homogenisation temperatures, most of the data fall within a vertical to sub-vertical narrow band (Fig. 7), suggesting strongly varying salinity associated with a small to moderate variation of homogenisation temperature.

\section{$\mathrm{O}, \mathrm{C}$, and Sr isotopes}

The stable isotope compositions $\left(\delta^{18} \mathrm{O}\right.$ and $\left.\delta^{13} \mathrm{C}\right)$ of carbonates from the Rubian, Buxan and Mao sections are listed in Table 6 and plotted in Fig. 8. The stable isotope compositions are similar in samples collected in outcrop and those from boreholes, which indicate that weathering did not affect substantially isotope composition. Magnesite from Rubian yields $\delta^{18} \mathrm{O}$ values ranging from 13.3 to 17.2\%o (mean: $15.0 \pm 1.0 \%$ o). Corresponding $\delta^{13} \mathrm{C}$ values range from -2.3 to $2.4 \%$ (mean: $0.60 \pm 1.0 \%$ o). The $\delta^{18} \mathrm{O}$ and $\delta^{13} \mathrm{C}$ values of the Mao calcite range from 17.7 to $22.7 \%$ o (mean: $19.9 \pm 1.7 \%$ ) and -0.3 to $1.5 \%$ o (mean: $0.6 \pm$ $0.6 \%$ ), respectively, and fall within the ranges observed for Buxan dolomite but are clearly differentiated from the respective values of Rubian carbonates (Table 6; Fig. 8). Magnesite-related Rubian dolomite has $\delta^{18} \mathrm{O}$ values ranging from 12.0 to $15.4 \%$ o (mean: $14.4 \pm 1.1 \%$ ). These are lighter than those of magnesite-free Buxan dolomite, which range from 17.1 to $20.2 \%$ (mean: $19.4 \pm 1.0 \%$ ). Rubian

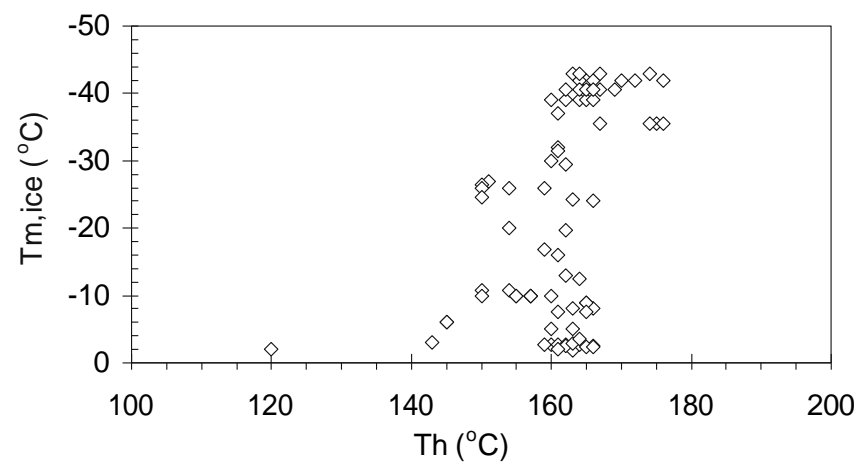

Fig. 7 Plot of $T_{\mathrm{m} \text {,ice }}$ vs homogenisation temperature for two-phase fluid inclusions in magnesite 
Table 6 O, C and Sr isotope data of Rubian, Buxan and Mao carbonates; calculated initial Sr at 290 Ma also shown

\begin{tabular}{|c|c|c|c|c|c|c|c|c|}
\hline Sample & Mineral & $\delta^{18} \mathrm{O} \%$ (SMOW) & $\delta^{13} \mathrm{C} \%$ (PDB) & ${ }^{87} \mathrm{Sr} /{ }^{86} \mathrm{Sr}$ & Sr (ppm) & $\mathrm{Rb} / \mathrm{Sr}$ & ${ }^{87} \mathrm{Rb} /{ }^{86} \mathrm{Sr}$ & ${ }^{87} \mathrm{Sr} /{ }^{86} \mathrm{Sr}(290 \mathrm{Ma})$ \\
\hline MAO-2 & Calcite & 19.53 & 1.54 & & & & & \\
\hline MAO-4 & Calcite & 18.83 & 1.25 & 0.70902 & 269 & 0.0446 & 0.1291 & 0.70849 \\
\hline MAO-11 & Calcite & 22.69 & -0.32 & & & & & \\
\hline MAO-12 & Calcite & 20.24 & 0.86 & 0.71008 & 270 & 0.0267 & 0.0772 & 0.70976 \\
\hline MAO-16 & Calcite & 17.69 & -0.21 & & & & & \\
\hline BUX-3 & Dolomite & 19.33 & 0.22 & & & & & \\
\hline BUX-6 & Dolomite & 20.08 & -0.21 & 0.71037 & 21 & 0.1312 & 0.3797 & 0.7088 \\
\hline BUX-8 & Dolomite & 20.11 & 0.94 & 0.70948 & 14.6 & 0.1699 & 0.4916 & 0.70671 \\
\hline BUX-13 & Dolomite & 20.08 & 0.91 & 0.70912 & 14.2 & 0.3042 & 0.8804 & 0.70538 \\
\hline SP2-1 & Dolomite & 12.06 & -1.07 & & & & & \\
\hline SP2-2 & Dolomite & 14.85 & 1.88 & & & & & \\
\hline SP2-4 & Dolomite & 15.23 & 1.41 & & & & & \\
\hline SP2-7 & Dolomite & 15.01 & 1.53 & & & & & \\
\hline SP4-2 & Dolomite & 14.15 & -1.43 & & & & & \\
\hline SP4-10 & Dolomite & 15.38 & 0.39 & & & & & \\
\hline SP4-1 & Dolomite & 21.37 & -2.64 & & & & & \\
\hline SP2-1 & Magnesite & 14.77 & 0.68 & & & & & \\
\hline SP2-2 & Magnesite & 13.77 & 1.76 & & & & & \\
\hline SP2-3 & Magnesite & 16.13 & 1.72 & & & & & \\
\hline SP2-18 & Magnesite & 15.38 & 0.33 & & & & & \\
\hline SP4-1 & Magnesite & 14.76 & -2.32 & 0.71521 & 152 & 0.0893 & 0.2585 & 0.71415 \\
\hline SP4-2 & Magnesite & 14.46 & -0.61 & & & & & \\
\hline SP4-3 & Magnesite & 16.12 & 0.07 & & & & & \\
\hline SP4-4 & Magnesite & 15.56 & 0.04 & 0.71143 & 0.48 & 0.5979 & 1.731 & 0.70429 \\
\hline SP4-5 & Magnesite & 14.11 & 0.15 & & & & & \\
\hline SP4-6 & Magnesite & 13.86 & 0.55 & 0.71462 & 4.3 & 5.518 & 15.98 & 0.71123 \\
\hline SP4-7 & Magnesite & 14.58 & 1.02 & 0.71559 & 7.7 & 1.103 & 3.193 & 0.71494 \\
\hline SP4-8 & Magnesite & 14.37 & 0.99 & & & & & \\
\hline SP4-9 & Magnesite & 13.32 & 1.11 & & & & & \\
\hline SP4-10 & Magnesite & 13.96 & 1.18 & 0.71425 & & 0.0546 & 0.158 & 0.71360 \\
\hline
\end{tabular}

dolomite also has $\delta^{13} \mathrm{C}$ values that range from -1.4 to $1.9 \%$ (mean: $0.4 \pm 1.3 \%$ ). These partly overlap and are slightly depleted by up to $-1.2 \%$, compared to those of Buxan dolomite, which has $\delta^{13} \mathrm{C}$ values between -0.2 and $1.9 \%$ (mean: $0.8 \pm 0.6 \%$ ) (Table 6; Fig. 8). An exception is sample SP4-1 (Rubian dolomite), which shows an enrichment in $\delta^{18} \mathrm{O}\left(21.4 \%\right.$ ) and a depletion in $\delta^{13} \mathrm{C}(-2.6 \%)$ and has been excluded from further consideration.
The ${ }^{87} \mathrm{Sr} /{ }^{86} \mathrm{Sr}$ ratios of Mao calcite (three), Buxan dolostone (five) and Rubian magnesite (five) are listed in Table 6 and the corrected ratios to 290 Ma plotted against $\delta^{18} \mathrm{O}_{\mathrm{SMOW}}$ are in Fig. $9 .{ }^{87} \mathrm{Sr}^{86} \mathrm{Sr}_{290}$ ratios vary from 0.70849 to 0.70976 for the Mao calcite and from 0.70538 to 0.70880 for the Buxan dolostone. With the exception of one sample - SP4-4 (0.70429) which has very low $\mathrm{Sr}$ content (0.48 ppm; Table 4) - the ${ }^{87} \mathrm{Sr} /{ }^{86} \mathrm{Sr}$ ratios in Rubian 


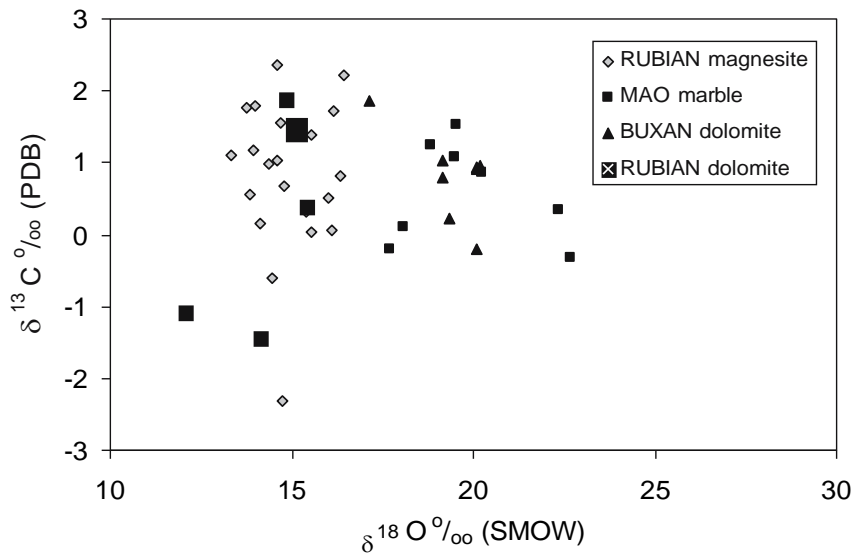

Fig. 8 Carbon and oxygen isotope plot of Rubian magnesite and dolomite, Buxan dolomite and Mao calcite

magnesite are more radiogenic and ${ }^{87} \mathrm{Sr} /{ }^{86} \mathrm{Sr}$ ranges from 0.71123 to 0.71494 .

\section{Discussion}

We believe the geological, textural, mineralogical and geochemical features shown by the Rubian magnesite and associated carbonates support an epigenetic origin for the magnesite deposit, via hydrothermal/metasomatic replacement of a dolomitic protolith by influx of hot Mg-rich hydrothermal fluids. This is in contrast to previous interpretations (Guillou 1970; Doval et al. 1977), which suggest that magnesite formation being via diagenetic transformation of Mg-rich carbonates initially deposited in a hypersaline lagoon, and provides new insights on the genesis of sparry magnesite deposits hosted by carbonate rocks in tectonised and metamorphosed terrains. The particular lines of evidence that we consider to support our hypothesis are outlined below.

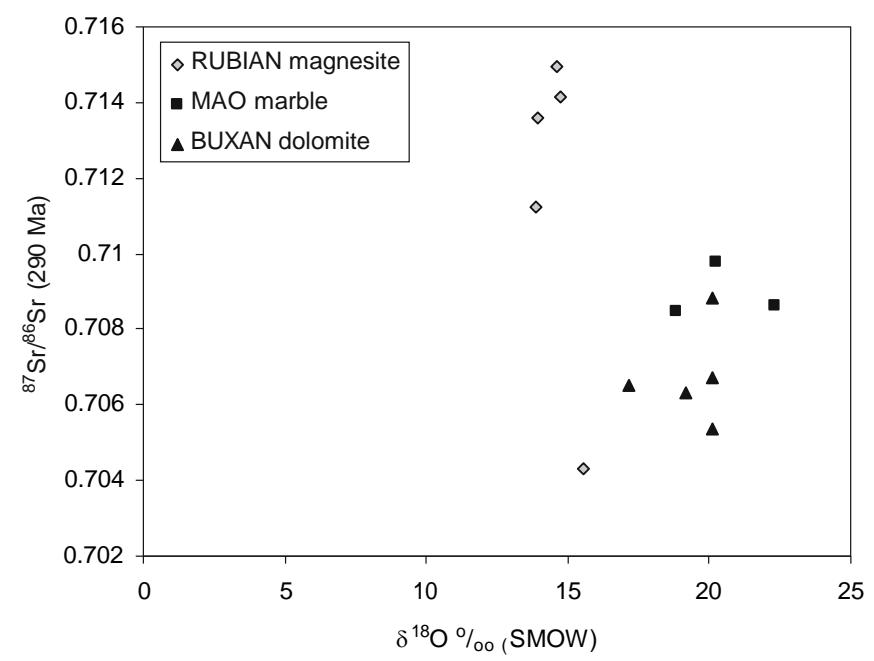

Fig. $9{ }^{87} \mathrm{Sr} /{ }^{86} \mathrm{Sr}-\delta^{18} \mathrm{O}$ plot of Rubian magnesite, Buxan dolomite and Mao calcite; ${ }^{87} \mathrm{Sr} /{ }^{86} \mathrm{Sr}$ ratios are corrected to $290 \mathrm{Ma}$
Textural-mineralogical and REE evidence

The morphology of the magnesite crystals and the existence of primary fluid inclusions indicate that magnesite is a neoformed mineral. In addition, all studied magnesite contain irregularly distributed dolomite inclusions (Fig. 3c). This and other textures such as the "zebra banding", replacement of magnesite back to dolomite (Fig. 4b), as well as quartz and apatite inclusions in magnesite, cannot be explained simply by diagenetic or metamorphic recrystallisation of a former microcrystalline magnesite deposit. Dolomite inclusions are interpreted as relics of a dolostone precursor that has been hydrothermally replaced by Mg-rich fluids to form sparry magnesite (Lugli et al. 2002). Furthermore, "zebra banding" in magnesite has been interpreted as a replacement feature of magnesite after dolomite (Lugli et al. 2000). The replacement of magnesite back to dolomite (Fig. 4b) is a characteristic feature of hydrothermal metasomatic magnesite deposits formed by replacement of dolostone such as Rum Jungle (Aharon 1988) and Eugui (Lugli et al. 2000). This feature has been ascribed to a reversal of the order of dolomite by magnesite mineral replacement due to the cumulative effect of the release of substantial amount of $\mathrm{Ca}^{2+}$ into the fluid during the replacement of dolomite by magnesite (Aharon 1988). This interpretation is supported by the similarity of the REE concentrations and patterns between Rubian magnesite (chondrite normalised values: 0.28-5.78, mean: 1.31) and Buxan dolostone (chondrite normalised values: 0.69-5.38, mean: 1.90) (Fig. 5). Furthermore, a hydrothermal origin for magnesite is indicated by the REE profiles that lack features typical of sedimentary magnesite such as negative Ce anomaly (Möller 1989; Bau and Moller 1992) and by the total abundances of the REE (Möller 1989). Magnesite deposited directly from hydrothermal fluids would be practically LREE-free (Lugli et al. 2000, 2002) because REE are fractionated in less soluble Ca-carbonates (Möller 1989). Rubian magnesite have probably consequently acquired their LREE from the dolomite inclusions and/or mineral impurities included in them (Lugli et al. 2000) during hydrothermal/metasomatic replacement. A further support for a hydrothermal/metasomatic origin stems from the similarity of total REE contents of Rubian magnesite to those of sparry and microcrystalline magnesite which have been demonstrably formed by hydrothermal/metasomatic replacement of a dolomite precursor, such as those from the Eugui deposit (chondrite normalised values between 0.1 and 25.0 (Lugli et al. 2000) and the Burano deposit (chondrite normalised values between 0.1 and 2.0 (Lugli et al. 2002)).

Fluid inclusion evidence and possible trapping conditions

Microthermometric data indicate that fluids trapped in primary fluid inclusions in Rubian magnesite are brines characterised by high and variable bulk total salinities (3.3 
to $29.5 \mathrm{wt} \%$ salts) belonging to the $\mathrm{MgCl}_{2}-\mathrm{NaCl}-\mathrm{CaCl}_{2}-$ $\mathrm{H}_{2} \mathrm{O}$ system.

As there is no evidence of fluid boiling or presence of $\mathrm{CO}_{2}$, the salinity variation in Fig. 7 may be interpreted as the result of local mixing of two fluids (e.g. Dubessy et al. 2003) with different salinities, temperatures and possibly $\mathrm{Mg} /(\mathrm{Ca}+\mathrm{Mg})$ ratios. Plumlee et al. (1994) have shown that, in Mississippi Valley-type deposits, dolomitisation may be produced by fluid/carbonate rock reaction accompanying fluid mixing, when the fluids become undersaturated with dolomite due to fluid mixing reactions. An alternative to local fluid mixing is the migration of pulses of brines with variable salinities that reflect largescale processes within the source aquifers and along the fluid path (Leach et al. 1997). Much of the variation in salinity in Rubian magnesite may be related to inherent variations in salinity within the fluid aquifer(s) (e.g. Palaeozoic sequence) produced by fluid mixing within the pile. The expulsion of fluids (heat driven, see below) from the host Palaeozoic sequence, containing a range of fluid salinities, would likely result in transient changes in fluid salinity at any given location along the brines' flow path. Fluid-rock reactions as well as additional fluid mixing during brine migration would further add to the variability.

The similarities between the Rubian fluid inclusion data and those from other $\mathrm{N}$ Iberian hydrothermal deposits formed by replacement of dolomitised Palaeozoic carbonate rocks such as: (1) the Eugui magnesite deposit ( $T_{\text {trapping: }}$ $\sim 150^{\circ} \mathrm{C}$ ) (Velasco et al. 1987), (2) the talc deposits of Puebla de Lillo ( $T_{\text {trapping }}: 280-400^{\circ} \mathrm{C}, P_{\text {fluid }}: 165-450$ bar) (Tornos and Spiro 2000) and their equivalent (Spiro et al. 1995) epithermal $\mathrm{Au}, \mathrm{As}-\mathrm{Au}, \mathrm{Cu}$ and $\mathrm{Hg}$ deposits of the Villamanin area ( $T_{\text {trapping: }} 100-240^{\circ} \mathrm{C}$ ) (Paniagua et al. 1993; Crespo et al. 2002), (3) the Sierra Menera magnesite-siderite deposits ( $T_{\text {trapping }}: 100-150^{\circ} \mathrm{C}, P_{\text {fluid }}$ : 100-150 bar) (Fernandez-Nieto et al. 2003) and (4) the Picos de Europa MVT-type $\mathrm{Zn}-\mathrm{Pb}$ sulphide deposits ( $T_{\text {trapping: }} 170-200^{\circ} \mathrm{C}, P_{\text {fluid }} \sim 100$ bar) (Gomez-Fernandez et al. 2000) illustrate the common genetic association with $\mathrm{NaCl}-\mathrm{MgCl}_{2}-\mathrm{CaCl}_{2}-\mathrm{H}_{2} \mathrm{O}$ brines with highly variable salinities (0-30 wt\% $\mathrm{NaCl}$ equivalent) and suggest a link with hydrothermal/metasomatic processes. Furthermore, based on these similarities, it may be suggested that the Rubian brines have been trapped under hydrostatic pressure conditions at shallow crustal depths.

The $P-T$ conditions of fluid trapping at Rubian are difficult to constrain due to the lack of mineralogical or paleogeographical indicators. To give an estimate of the possible $P-T$ conditions of fluid inclusion trapping, we have used the points of intersection of calculated fluid inclusion isochores with the hydrostatic and lithostatic thermobaric gradients supposed to have existed at the time of fluid trapping. Following the methodology of Gasparrini (2003), isochores were constructed for fluid inclusions of known salinity which have the minimum and maximum $T_{\mathrm{h}}$, respectively, without considering those inclusions having too low $\left(92^{\circ} \mathrm{C}\right)$ or too high $\left(235^{\circ} \mathrm{C}\right)$ values relative to the normal distribution of data (Fig. 10). The isochores were

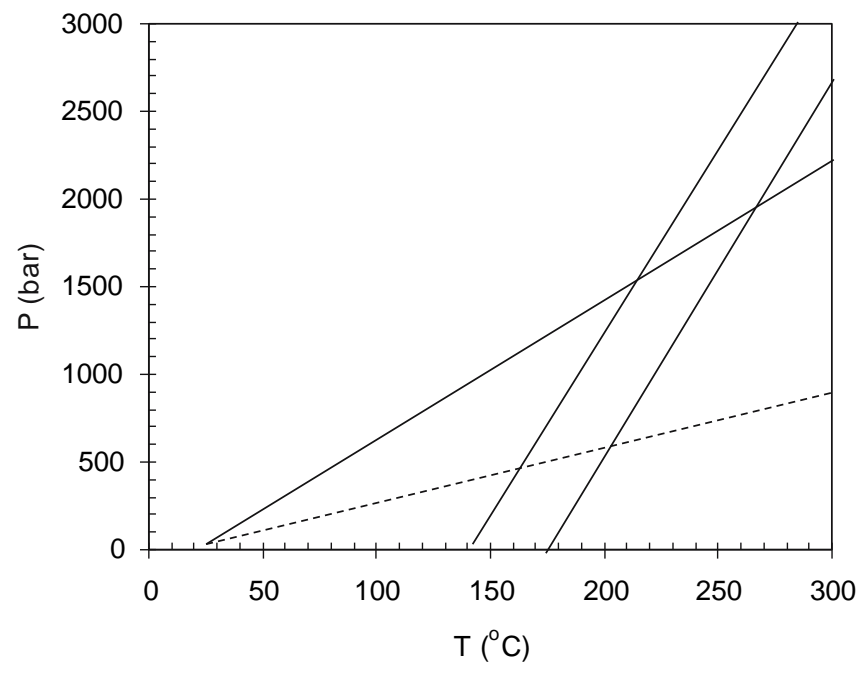

Fig. $10 P-T$ plots showing the hydrostatic and lithostatic gradients and their intersection points with isochores constructed from the minimum and maximum $T_{\mathrm{h}}$ values

constructed in the system $\mathrm{H}_{2} \mathrm{O}-\mathrm{NaCl}$ according to the model of Bodnar and Vityk (1994) using the program LONER 32 (Bakker 2001, 2003). A geothermal gradient of $35^{\circ} \mathrm{C} / \mathrm{km}$ and geobarometric gradients of 101 and $271 \mathrm{bar} / \mathrm{km}$ for hydrostatic and lithostatic conditions, respectively, were selected (see, for a review, Gasparrini 2003). The isochore constructed for the minimum $T_{\mathrm{h}}$ value $\left(140^{\circ} \mathrm{C}\right.$; Fig. 10) crosses the hydrostatic gradient at $165^{\circ} \mathrm{C}$ and 400 bar and the lithostatic gradient at $220^{\circ} \mathrm{C}$ and 1,500 bar; these correspond to depths of approximately 4 and $5.5 \mathrm{~km}$, respectively. The isochore constructed for the maximum $T_{\mathrm{h}}$ value $\left(176^{\circ} \mathrm{C}\right.$; Fig. 10$)$ crosses the hydrostatic gradient at $200^{\circ} \mathrm{C}$ and 500 bar and the lithostatic gradient at $270^{\circ} \mathrm{C}$ and 2,000 bar; these correspond to depths of approximately 5 and $7.5 \mathrm{~km}$, respectively. Considering that the timing for the dolomitisation and magnetisation coincide with the regional late-Variscan high heat flow (Gutierrez-Alonso et al. 2004; also see below), the geothermal gradient of the study area at the time of mineralisation was likely to be higher than the selected gradient of $35^{\circ} \mathrm{C} / \mathrm{km}$. The trapping temperatures calculated based on this gradient are consequently the maximum possible temperatures for the mineralising fluids (see, for a review, Gasparrini 2003). Therefore, the real temperature of the Rubian magnesite formation is most probably between the measured $T_{\mathrm{h}}$ with mode at $160^{\circ} \mathrm{C}$ and a temperature of 200 or $270^{\circ} \mathrm{C}$ for hydrostatic or lithostatic pressure, respectively, with a gradient of $35^{\circ} \mathrm{C} / \mathrm{km}$ (Fig. 10). If the trapping pressure regime at Rubian has been entirely hydrostatic, then the above calculations would indicate maximum $P_{\text {fluid }}$ of 500 bar at $T_{\text {fluid }} \sim 200^{\circ} \mathrm{C}$ corresponding to maximum hydrostatic load and depth of magnesite formation of $\sim 5 \mathrm{~km}$. These estimates agree with the $P-T$ conditions of formation of the Eugui magnesite deposit with a very similar mode of $T_{\mathrm{h}}$ values $\left(160^{\circ} \mathrm{C}\right.$; Velasco et al. 1987). A comparison with fluid inclusion data of the Burano magnesite (Lugli et al. 2002) would suggest 
temperatures of $300^{\circ} \mathrm{C}$ or even more. However, these temperatures would indicate unrealistic hydrostatic $P_{\text {fluid }}$ $>2.5$ kbar corresponding to unrealistic depths of $>20 \mathrm{~km}$ for magnesite formation at Rubian (Fig. 10).

\section{Isotope evidence}

The oxygen and carbon isotope values of Rubian magnesite (Fig. 8; Table 6) overlap partly or wholly with those reported for metasomatic sparry magnesite formed by dolomite replacement (Aharon 1988; Kralik et al. 1989; Lugli et al. 2002), and differ from those of magnesite from recent playas and sabkhas, which have heavier oxygen and carbon isotope compositions (Melezhik et al. 2001).

Mao calcite has $\delta^{18} \mathrm{O}$ lower than typical marine limestones $\left(\delta^{18} \mathrm{O}\right.$ : 25.2-28.6\%; Veizer and Hoefs 1976) and $\delta^{13} \mathrm{C}$ values that overlap with average $\delta^{13} \mathrm{C}$ values of Phanerozoic marine limestones $(-2.0$ to $+6.0 \%$; Veizer et al. 1999) in keeping with carbon derived from marine carbonate. The ${ }^{18} \mathrm{O}$ depletion may be due to isotope exchange between the carbonates and fluids with an external source of light oxygen or isotope exchange with ${ }^{16}$ O-rich pelitic rocks (Valley 1986). Rubian dolomite is depleted by around 5\%o compared to Buxan dolomite and this ${ }^{18} \mathrm{O}$ depletion may be interpreted in several ways (see, for a review, Tornos and Spiro 2000, and references therein). When such ${ }^{18} \mathrm{O}$ depletion between barren and mineralisation-related dolostone is accompanied by evidence of metasomatic replacement processes and concomitant Sr isotope variations (see below and Fig. 9), it may be interpreted as a result of the influx of ${ }^{18} \mathrm{O}$-poor waters accompanied by a temperature increase in a fluiddominated system (Tornos and Spiro 2000).

The overlapping of isotope values for Rubian dolomite and magnesite in the $\delta^{18} \mathrm{O}-\delta^{13} \mathrm{C}$ plot (Fig. 8) require either different temperatures in a common hydrothermal system or different fluid isotope values as the fractionation factors of the two minerals for both systems are different. To test the hypothesis of a common hydrothermal system, the $\delta^{18} \mathrm{O}$ isotope composition of the fluid in equilibrium with Rubian magnesite and dolomite was calculated for temperatures up to $400^{\circ} \mathrm{C}$, using the carbonate isotope data (Table 6) and isotope fractionation equations for magnesite- $\mathrm{H}_{2} \mathrm{O}$ and dolomite- $\mathrm{H}_{2} \mathrm{O}$ (Zheng 1999); the results are shown in Fig. 11. $\delta^{18} \mathrm{O}_{\text {fluid }}$ values for fluids in equilibrium with Rubian dolomite and magnesite are very similar (Fig. 11), suggesting that dolomitisation and magnesite formation were produced by the same hydrothermal system at different temperatures. As shown in Fig. 8, Mao calcite and Buxan dolomite have a narrow range of largely overlapping $\delta^{13} \mathrm{C}$ values (approximately 1.9-2.1\%o); Rubian dolomite and magnesite show a relatively larger variation toward more negative $\delta^{13} \mathrm{C}$ values. These features may be interpreted in several ways: (1) progressive interaction with a hydrothermal fluid (e.g. GomezFernandez et al. 2000, and references therein), (2) mixing of different waters (Velasco et al. 2003), (3) changes in $\mathrm{pH}$, temperature and/or $\mathrm{fO}_{2}$ conditions that control the isotope composition of the fluids (Ohmoto 1986) and (4) temperature/depth dependence of diagenetic $\mathrm{CO}_{2}$ from (exotic?) pore water reservoir (Dix et al. 1995). Our preferred interpretation is that the variability in $\delta^{13} \mathrm{C}$ values results from fluid/rock reactions.

The oxygen isotope composition of fluids in equilibrium with Rubian magnesite and dolomite at $200^{\circ} \mathrm{C}$ is $\delta^{18} \mathrm{O}_{\text {fluid }}$ $\sim+5.0 \%$ o (Fig. 11); the corresponding $\delta^{13} \mathrm{C}_{\text {fluid }}$ values are $+0.2 \pm 1.0$ and $-0.2 \pm 1.4 \%$ o $\left(200^{\circ} \mathrm{C}\right)$.

The ${ }^{87} \mathrm{Sr} /{ }^{86} \mathrm{Sr}$ ratios of the Mao calcite fall in the range of Sr isotope ratios of early Cambrian seawater $(\sim 0.709$; Faure 1986; Ebneth et al. 2001), suggesting protolith formation from seawater and subsequent recrystallisation processes in a closed system relative to $\mathrm{Sr}$ or in equilibrium with water of similar Sr isotope composition (Banner
Fig. 11 Calculated $\delta^{18} \mathrm{O}$ of fluids in equilibrium with Rubian magnesite and dolomite

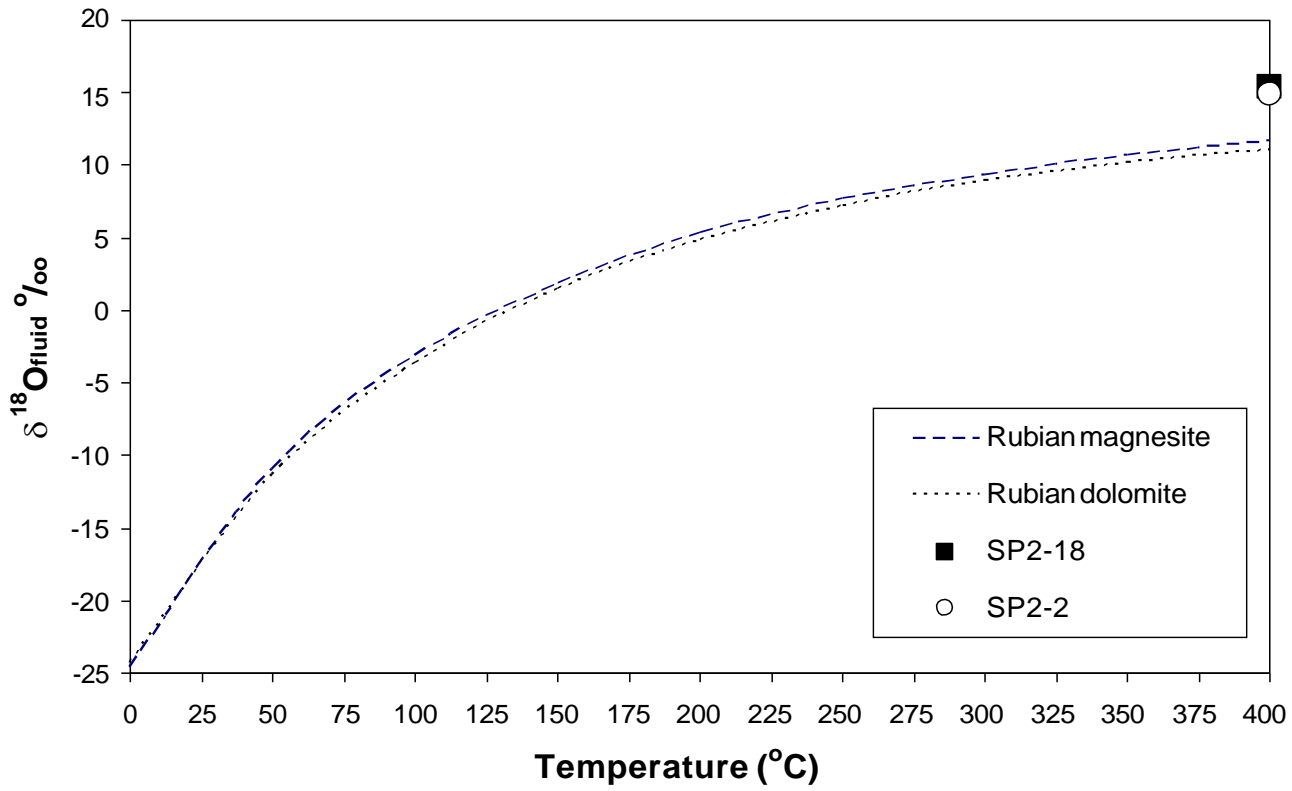


1995). Excluding one sample, the ${ }^{87} \mathrm{Sr} /{ }^{86} \mathrm{Sr}$ ratios in Rubian magnesite are more radiogenic than those of seawater over geological times and compared to $\mathrm{MaO}$ and Buxan rocks. This indicates that host rocks at Rubian interacted with ${ }^{87} \mathrm{Sr}$-enriched fluids. The fluids may have acquired their radiogenic ${ }^{87} \mathrm{Sr}$ by interaction with interbedded or underlying meta-clastic lithologies, rich in Rbbearing minerals. The possible mechanisms may include leaching of feldspars or micas by mineralogical changes into clays and chlorites or by interlayer cation exchange (Moritz et al. 1996). The same radiogenic ${ }^{87} \mathrm{Sr}$ enrichment relative to host rocks was reported for regional hydrothermal dolomite replacing late Carboniferous limestones (Gasparrini et al. 2003) and hydrothermal dolostone replacing Carboniferous limestones hosting a talc deposit (Tornos and Spiro 2000); this enrichment was attributed to fluid equilibration with siliciclastic rocks. A contribution of Sr derived from igneous rocks cannot be evaluated for Rubian due to the lack of data from igneous rocks in the area. The Precambrian to Middle Devonian shales reported in Gasparrini (2003) and Tornos and Spiro (2000) have ${ }^{87} \mathrm{Sr} /{ }^{86} \mathrm{Sr}$ ratios distinctly higher than those of the studied magnesite. Such siliciclastic materials were the most possible source of radiogenic ${ }^{87} \mathrm{Sr}$. In the ${ }^{87} \mathrm{Sr} /{ }^{86} \mathrm{Sr}-\delta^{18}$ $\mathrm{O}_{\text {SMOw }}$ plot (Fig. 9), Rubian magnesite show the most radiogenic $\mathrm{Sr}$ and the lowest $\delta^{18} \mathrm{O}$ values compared to all the other carbonates; this, in conjunction with $\delta^{18} \mathrm{O}-\delta^{13} \mathrm{C}$ relationships (Fig. 8), may be interpreted as reaction of carbonate rocks (dolostone) with radiogenic "shale"equilibrated fluids at progressively higher temperatures and fluid/rock ratios (Tornos and Spiro 2000).

The isotope composition of the magnesite-forming fluid $\left(\delta^{18} \mathrm{O}:+5 \%\right.$; $\delta^{13} \mathrm{C} \sim-0.2$ to $+0.2 \%$; $T \sim 200^{\circ} \mathrm{C}$ ) is consistent with "pseudo-metamorphic" or "formation" fluids (i.e. modified basinal brines) that have equilibrated with detrital metamorphic rocks (e.g. Tornos and Spiro 2000).

\section{Origin of magnesite}

Clear evidence has been presented that the Rubian magnesite mineralisation was genetically related to Mgrich hydrothermal brines, formed by the metasomatic replacement of hydrothermal dolomite, and that the dolomitisation and the magnesite mineralisation were produced by the same hydrothermal system at different temperatures. Furthermore, whereas dolomitisation seems to be a regional feature, magnesite mineralisation appears to depend on local conditions. In the light of the geological setting of Rubian, the critical factors necessary for the formation of magnesite instead of regional dolomite were consequently: (1) a major driving mechanism that would result in a substantial increase of heat flow to produce enough energy for the mobilisation of mineralising hydrothermal brines, (2) heat-driven uplift that would cause the required extensional tectonics for the channelling of the mineralising fluids, (3) a local thermal anomaly to provide the extra heat to shift the mineral stability from dolomite to magnesite that is temperature dependent and,
(4) a source of Mg to supply the Mg content of the fluids. There is no evidence in NW Iberia of an event that would be able to provide all these necessary genetic conditions more recently than the regional late-Variscan large-scale magmatism and high heat and fluid flow scenario in which orocline-triggered lithospheric delamination played a key role (Fernandez-Suarez et al. 2000; Gutierrez-Alonso et al. 2004). The regional hydrothermal dolomitisation of Palaeozoic (L. Cambrian-L. Carboniferous) carbonates in NW Iberia as well as in several regions of central and western Europe has been genetically related to this lateVariscan high heat and fluid flow event (Boni et al. 2000; Grimmer et al. 2000; Iannace et al. 2001; Gasparrini 2003; Gasparrini et al. 2003). The genetic model for these hydrothermal dolomite invokes extensional tectonics to promote gravity-driven flow of pore- or pre-concentrated hot $\left(100-150^{\circ} \mathrm{C}\right)$, high-salinity $\mathrm{NaCl}-\mathrm{MgCl}_{2}-\mathrm{CaCl}_{2}-\mathrm{H}_{2} \mathrm{O}$ brines, which dolomitised the more permeable, mostly Carboniferous, carbonate rocks close to long-lived fault lines.

The possible genetic link of Rubian mineralisation with the late-Variscan hydrothermal event is supported by common fluid characteristics (see "Fluid inclusions"; Boni et al. 2000; Grimmer et al. 2000; Iannace et al. 2001; Gasparrini 2003; Gasparrini et al. 2003) as well as indirect evidence for a late-Variscan age of dolomitisation and magnesite formation at Rubian. Rubian dolomite and magnesite are later than the last Variscan deformation episodes in the West Asturian Leonese Zone because neither Rubian dolomite nor magnesite bear evidence of extensional shearing or fold-related deformation. Furthermore, bedding parallel stylolites do not affect either Rubian dolomite or magnesite, suggesting that they post-date stylolite development. The intrusion ages of post-tectonic granitoids in the West Asturian Leonese Zone indicate that the main Variscan deformation event in this zone ended before c.295 Ma (Fernandez-Suarez et al. 2000) and provides a lower constraint for the timing of dolomitisation and magnesitisation at Rubian. In addition, orocline development in NW Iberia lasted until $285 \mathrm{Ma}$ (Gutierrez-Alonso et al. 2004); this may represent the upper constraint for the timing of the Rubian dolomitisation/magnesitisation.

Taking into account the geological setting of Rubian high-salinity Mg-fluids invoked to have formed the magnesite, they may have been produced by Mg-liberating metamorphic reactions in pelitic meta-sediments (Morteani et al. 1983; Lugli et al. 2002). The presence of Mg-rich chlorites (clinochlore) in mica-schists could provide evidence that significant amounts of $\mathrm{Mg}$ may have been produced during their formation. Diagenetic clay or illite, a likely precursor of the Mg-rich chlorites (Aharon 1988) within the Palaeozoic sedimentary protolith, may have released significant amounts of $\mathrm{Mg}, \mathrm{Na}, \mathrm{Ca}, \mathrm{Fe}$ and $\mathrm{Cl}$ during metamorphism (e.g. Michalik 1997). The Viveiro Fault may have played a crucial role for local fluid circulation by allowing fluids to reach permeable carbonate horizons.

The Tornos and Spiro (2000) model for talc formation (Puebla de Lillo-Cantabrian Zone, N Spain) by the 
metasomatic replacement of dolomitised limestone provided the basic principles for the genesis of the Rubian magnesite deposit. However, at Rubian, metasomatism was at lower temperatures and/or higher $\mathrm{XCO}_{2}$. In addition, the common genetic rules between Rubian and Puebla de Lillo suggest that the formation of hydrothermal replacive magnesite can be treated as a problem of zonation within a metasomatic column - magnesite formation is restricted to very high permeability zones (e.g. faults) and higher fluid/rock ratios, whereas dolomite tends to be located in the more extensive lower permeability regions and lower fluid/rock ratios. In addition, magnesite formation may have been aided by extra heat from intrusive dykes or subcropping igneous bodies that raised the local isotherms, thus allowing for the transition from the stability field of dolomite to that of magnesite (Johannes 1970).

\section{Conclusions}

The mineralogical, textural, REE, fluid inclusion and isotope characteristics of the mineralisation in the Rubian magnesite deposit are consistent with a metasomatic hydrothermal origin for the magnesite by replacement of a dolostone precursor during fluid/rock reaction with hot Mg-rich fluids. The mineralising fluids were brines characterised by highly variable salinities (3.5 to $29.5 \mathrm{wt} \%$ salts), belonging to the $\mathrm{MgCl}_{2}-\mathrm{NaCl}-\mathrm{CaCl}_{2}-\mathrm{H}_{2} \mathrm{O}$ system. Variable salinity may be the result of a combination of fluid mixing, a migration of pulses of brines with variable salinities that reflect large-scale processes within the source aquifers and along the fluid migration path and local dissolution and replacement processes of the host dolostone during the formation of the magnesite. These fluids may represent modified basinal brines that have reacted and equilibrated with siliciclastic metamorphic rocks. Metamorphic reactions involving clastic meta-sediments, intercalated within the host carbonate sequence, could have been the source of $\mathrm{Mg}$ in the fluids. Magnesite formation was genetically linked to dolomitisation-related hydrothermal processes of possible late-Variscan times; magnesite formation occurred by the reaction of dolostone with the same hydrothermal fluid at maximum $P_{\text {fluid }}$ of $500 \mathrm{bar}$ and $T_{\text {fluid }} \sim 200^{\circ} \mathrm{C}$ corresponding to a maximum hydrostatic depth of $\sim 5 \mathrm{~km}$. This hydrothermal event was probably related to regional late-Variscan high heat flow and extensional tectonics. This occurred during uplift and thinning of the upper crust after the Variscan collisional stages in the NW Iberian Belt, in which orocline-triggered lithospheric delamination played a key role. The formation of hydrothermal replacive magnesite is a result of a metasomatic column with magnesite forming at higher fluid/rock ratios than dolomite and was possibly aided by extra heat from intrusive dykes or sub-cropping igneous bodies that raised the local isotherms, thus allowing for the transition from the stability field of dolomite to that of magnesite. The Viveiro Fault may have played a crucial role for fluid circulation. The Rubian magnesite have textural, REE, fluid inclusion and isotope similarities to other sparry magnesite deposits in the Palaeozoic carbonate rocks of the Pyrenees in Spain, the eastern Alps in Austria and Slovakia, the western Carpathian Mountains and the Mississippi Valley-type $\mathrm{Zn}-\mathrm{Pb}$ and $\mathrm{Fe}$ deposits in the Basque-Cantabrian basin, which have been interpreted as hydrothermal metasomatic deposits formed by dolomite replacement (Morteani et al. 1983; Pohl and Siegl 1986; Velasco et al. 1987; Lugli et al. 2000, 2002).

Acknowledgements Financial support for this work has been provided by project BTE2001-1443 (Ministerio de Ciencia y Tecnologia). We wish to thank D.P. Rodriguez (Magnesitas de Rubian S.A.) for advising and for facilities given during the development of the investigation, and $M$. Regueiro and $M$. Lombardero (IGME) for collaboration during fieldwork. Thanks are also due to J.R. Martínez Catalán, R. Arenas and G. GutierrezAlonso for valuable discussions on the regional geology. We thank D.P.F. Darbyshire, NERC Isotope Geoscience Laboratory (NIGL) and J. Naden, British Geological Survey (BGS) for critical and constructive reviews of the manuscript. Acknowledgements are extended to F. Tornos for his critical review that significantly improved the original manuscript. Thanks are extended to geologist K. Detsi (National and Kapodistrian University of Athens-NKUA) for logistic help and to E. Michailidis (NKUA) for technical assistance with SEM-EDS analysis.

\section{References}

Aharon P (1988) A stable-isotope study of magnesites from the Rum Jungle Uranium Field, Australia: implications for the origin of strata-bound massive magnesites. Chem Geol 69:127-145

Aranguren A, Cuevas J, Tubia JM, Roman-Berdiel T, Casas-Sainz A, Casas-Ponsati A (2003) Granite laccolith emplacement in the Iberian arc: AMS and gravity study of the La Tojiza pluton (NW Spain). J Geol Soc (Lond) 60:435-445

Arenas R, Martínez Catalán JR (2003) Low-P metamorphism following a Barrovian-type evolution. Complex tectonic controls for a common transition, as deduced in the Mondoñedo thrust sheet (NW Iberian Massif). Tectonophysics 365:143-164

Bakker RJ (2001) FLUIDS: new software package to handle microthermometric data and to calculate isochores. In: Noronha F, Doria A, Guedes A (eds) XVI ECROFI European current research on fluid inclusions. Porto 2001, abstracts. Faculdade de Ciencias do Porto, Departamiento de Geologia. Memoria $7: 23-25$

Bakker RJ (2003) Package FLUIDS 1. Computer programs for analysis of fluid inclusion data and for modelling bulk fluid properties. Chem Geol 194:3-23

Bakker RJ (2004) Raman spectra of fluid and crystal mixtures in the systems $\mathrm{H}_{2} \mathrm{O}, \mathrm{H}_{2} \mathrm{O}-\mathrm{NaCl}$ and $\mathrm{H}_{2} \mathrm{O}-\mathrm{MgCl}_{2}$ at low temperatures: applications to fluid-inclusion research. Can Mineral 42:1283-1314

Banner JL (1995) Application of the trace-element and isotope geochemistry of strontium to studies of carbonate diagenesis. Sedimentology 42:805-824

Bau M, Moller P (1992) Rare earth element fractionation in metamorphogenic hydrothermal calcite, magnesite and siderite. Mineral Petrol 45:231-246

Bodnar RJ (1993) Revised equation and table for determining the freezing-point depression of $\mathrm{H}_{2} \mathrm{O}-\mathrm{NaCl}$ solutions. Geochim Cosmochim Acta 57:683-684

Bodnar RJ, Vityk MO (1994) Interpretation of microthermometric data for $\mathrm{H}_{2} \mathrm{O}-\mathrm{NaCl}$. In: De Vivo B, Frezzoti ML (eds) Fluid inclusions in minerals. Blacksburg, Virginia Polytechnic Institute, pp 117-130 
Boni M, Parente G, Bechstadt T, De Vivo B, Iannace A (2000) Hydrothermal dolomites in SW Sardinia (Italy): evidence for a widespread late-Variscan fluid flow event. Sediment Geol 131:181-200

Bustillo M, López-Jimeno C (1997) Manual de Evaluación y Diseño de Explotaciones Mineras. Entorno Gráfico, Madrid, p 705

Clyne MA, Potter RW (1977) Freezing point depression of synthetic brines (abstract]. Geological Society of America abstracts with programs, vol 19, p 930

Craig H (1957) Isotopic standards for carbon and oxygen and correction factors for mass spectrometric analysis of carbon dioxide. Geochim Cosmochim Acta 12:133-149

Crespo TM, Delgado A, Catena EV, García JAL, Fabre C (2002) The latest post-Variscan fluids in the Spanish Central System. Mar Pet Geol 19:323-337

Dallmeyer RD, Martínez-García E (Eds) (1990) Pre-Mesozoic geology of Iberia. Springer, Berlin Heidelberg New York, p 415

Dallmeyer RD, Martínez Catalán JR, Arenas R, Gil Ibarguchi JI, Gutierrez Alonso G, Farias F, Aller J (1997) Diachronous Variscan tectonothermal activity in the NW Iberian Massif: evidence from ${ }^{40} \mathrm{Ar} /{ }^{39} \mathrm{Ar}$ dating of regional fabrics. Tectonophysics 297:307-337

Davies DW, Lowenstein TK, Spenser RJ (1990) Melting behavior of fluid inclusions in laboratory-grown halite crystals in the systems $\mathrm{NaCl}-\mathrm{H}_{2} \mathrm{O}, \quad \mathrm{NaCl}-\mathrm{KCl}, \quad \mathrm{NaCl}-\mathrm{MgCl}_{2}-\mathrm{H}_{2} \mathrm{O}$, and NaCl- $\mathrm{CaCl}_{2}-\mathrm{H}_{2} \mathrm{O}$. Geochim Cosmochim Acta 54:591-601

Dix GR, Thomson ML, Longstaffe FJ (1995) Systematic decrease of high delta-C-13 values with burial in late Archean (2.8-Ga) diagenetic dolomite-evidence for methanogenesis from the Crixas Greenstone-belt, Brazil. Precambrian Res 70:253-268

Doval M, Brell JM, Galán E (1977) El yacimiento de magnesita de Incio (Lugo, España). Bol Geol Min 88:50-64

Dubessy J, Derome D, Sausse J (2003) Numerical modelling of fluid mixings in the $\mathrm{H}_{2} \mathrm{O}-\mathrm{NaCl}$ system application to the North Caramal U prospect (Australia). Chem Geol 194:25-39

Ebneth S, Shields GA, Veizer J, Miller JF, Shergold JH (2001) High-resolution strontium isotope stratigraphy across the Cambrian-Ordovician transition. Geochim Cosmochim Acta 65:2273-2292

Ellmies R, Voigtlander G, Germann K, Krupenin MT, Moller P (1999) Origin of giant stratabonnd deposits of magnesite and siderite in Riphean carbonate rocks of the Bashkir megaanticline, western Urals. Geol Rundsch 87:589-602

Fabricius J (1984) Formation temperature and chemistry of brine inclusions in euhedral quartz crystals from Permian salt in the Danish Trough. Bull Mineral 107:203-216

Faure G (1986) Principles of isotope geology. Wiley, New York, NY, p 589

Fernandez-Nieto C, Torres-Ruiz J, Subias-Perez I, Fanlo-Gonzalez I, Gomzalez-Lopez JM (2003) Genesis of Mg-Fe carbonates from the Sierra Menera magnesite-siderite deposits, northeast Spain: evidence from fluid inclusions, trace elements, rare earth elements, and stable isotope data. Econ Geol 98:1413-1426

Fernandez-Suarez J, Dunning GR, Jenner GA, Gutierrez-Alonso G (2000) Variscan collisional magmatism and deformation in NW Iberia: constraints from $\mathrm{U}-\mathrm{Pb}$ geochronology of granitoids. J Geol Soc (Lond) 157:565-576

Friedman I, O'Neil JR (1977) Compilation of stable isotope fractionation factors of geochemical interest. In: Fleischer $M$ (ed) Data of geochemistry. Ch KK US Geol Surv, Prof Pap 440KK 1-12

Gasparrini M (2003) Large-scale hydrothermal dolomitization in the southwestern Cantabrian Zone (NW Spain): causes and controls of the process and origin of the dolomitization fluids. Ph.D. thesis, University of Heidelberg, p 193

Gasparrini M, Bakker RJ, Bechstadt Th, Boni M (2003) Hot dolomites in a Variscan foreland belt: hydrothermal flow in the Cantabrian Zone (NW Spain). J Geochem Explor 78-79:501-507

Gómez de Llarena J (1959) Nuevas observaciones sobre la magnesita sedimentaria. Estud Geol 15:189-211
Gomez-Fernandez F, Both RA, Magnas J, Arribas A (2000) Metallogenesis of $\mathrm{Zn}-\mathrm{Pb}$ carbonate-hosted mineralization in the southeastern region of the Picos de Europa (central northern Spain) province: geologic, fluid inclusion, and stable isotope studies. Econ Geol 95:19-40

Grimmer JOW, Bakker RJ, Zeeh S, Bechstadt T (2000) Dolomitization and brecciation along fault zones in the Cantabrian mountains. J Geochem Explor 69-70:153-158

Guillou JJ (1970) Les magnesites cambriennes de Pacios (Province de Lugo-Espagne). Leur environnement paléogéographique. Bulletin du Bureau des Recherches Géologiques et Minières (2ème Sér.), sect IV, 3:5-20

Gutierrez-Alonso G, Fernandez-Suarez J, Weil AB (2004) Orocline triggered lothospheric delamination. Geol Soc Amer Bull 383:121-130

Iannace A, Boni M, Bechstadt T (2001) Late Variscan fluid-flow and hydrothermal dolomitisation: an European perspective? In: Piestrzyñski A et al (eds) Mineral deposits at the beggining of the 21st century. pp 197-200

IGME-Instituto Geologico Y Minero de Espana (1983) Geological map of Lugo (geological map of Spain 1/200,000). Instituto Geologico Y Minero de Espana, Madrid

Johannes W (1970) Zur Entstehung von Magnesitvorkommen. Neues Jahrb Mineral Abh 113:274-325

Kralik M, Aharón P, Schroll E, Zachmann D (1989) Carbon and oxygen isotope systematics of magnesites: a review. In: Möller $\mathrm{P}$ (ed) Magnesite geology, mineralogy, geochemistry, formation of Mg-carbonates. Monogr Ser Miner Depos 28:197-223

Leach DL, Apodaca LE, Repetski JE, Powell JW, Rowan EL (1997) Evidence for hot Mississippi Valley-type brines in the Reelfoot rift complex, south-central United States, in late Pennsylvanian-early Permian. US geological survey professional paper 1577, pp 36

Lotze F (1957) Zum Alter nordwestspanischer Quartzit-SandsteinFolgen. Neues Jahrb Geol Paläontol Monatsh 10:464-471

Lugli S, Torres-Ruiz J, Garuti G, Olmedo F (2000) Petrography and geochemistry of the Eugui magnesite deposit (Western Pyrenees, Spain): evidence for the development of a peculiar zebra banding by dolomite replacement. Econ Geol 95:1775-1791

Lugli S, Morteani G, Blamart D (2002) Petrographic, REE, fluid inclusion and stable isotope study of magnesite from the Upper Triassic Burano Evaporites (Secchia Valley, northern Apennines): contributions from sedimentary, hydrothermal and metasomatic sources. Miner Depos 37:480-494

Marcos A, Martínez Catalán JR, Gutiérrez Marco JC, Pérez-Estaún A (2004) Zona Asturoccidental-Leonesa. Estratigrafía y paleogeografía. In: Vera JA (ed) Geología de España. 49-52 SGE-IGME, Madrid

Martínez Catalán JR, Pablo JG (1978) Geological map of Sarria (sheet nr 124, geological map of Spain 1/50,000). Instituto Geológico Minero de España, Madrid

Martínez Catalán JR, Perez Estaun A, Bastida F, Pulgar JA (1990) West Asturian-Leonese Zone Structure. In: Dallmeyer RD, Martinez Garcia E (eds) Pre-Mesozoic geology of Iberia. Springer, Berlin Heidelberg New York, pp 103-114

Martínez Catalán JR, Rodríguez MPH, Alonso PV, Pérez-Estaún A, Lodeiro FG (1992) Lower Paleozoic extensional tectonics in the limit between the West Asturian-Leonese and Central Iberian Zones of the Variscan Fold-Belt in NW Spain. Geol Rundsch 81:545-560

Martínez Catalán JR, Arenas R, Díez Balda M (2003) Large extensional structures developed during emplacement of a crystalline thrust sheet: the Mondoñedo nappe (NW Spain). J Struct Geol 25:1815-1839

Mathews A, Katz A (1977) Oxygen isotope fractionation during dolomitization of calcium-carbonate. Geochim Cosmochim Acta 41:1431-1438

McCrea JM (1950) On the isotopic chemistry of carbonates and a paleotemperature scale. J Chem Phys 18:849-857 
Melezhik V, Fallick AE, Medvedev PV, Makarikhin VV (2001) Palaeoproterozoic magnesite: lithological and isotopic evidence for playa/sabkha environments. Sedimentology 48:379-397

Michalik M (1997) Chlorine containing illites, copper chlorides and other chloride bearing minerals in the Fore-Sudetic copper deposit (Poland). In: Papunen $\mathrm{H}$ (ed) Mineral deposits: research and exploration. Rotterdam Balkema, pp 543-546

Möller P (1989) Minor and trace elements in magnesite In: Moller P (ed) Magnesite: geology, mineralogy, geochemistry, formation of Mg-carbonates. Monogr Ser Miner Depos 28:173-196

Moritz RP, Fontbote L, Spangenberg J, Rosas S, Sharp Z, Fontignie D (1996) Sr, C and O isotope systematics in the Pucara basin, central Peru. Comparison between Mississippi Valley-type deposits and barren areas. Miner Depos 31:147-162

Morteani G, Schley F, Möller P (1983) On the formation of magnesite. In: Schneider HJ (ed) Mineral deposits of the Alps and of the Alpine Epoch in Europe. Springer, Berlin Heidelberg New York, pp 106-116

Naden J (1996) CalcicBrine: a Microsoft Excel 5.0 Add-in for calculating salinities from microthermometric data in the system $\mathrm{NaCl}-\mathrm{CaCl}_{2}-\mathrm{H}_{2} \mathrm{O}$. PACROFI VI, University of Wisconsin (abstact)

Niedermayr G, Beran A, Scheriau-Niedermayr E (1983) Magnesite in Permian and Scythian series of the eastern Alps, Austria, and its petrographic significance. In: Schneider HJ (ed) Mineral deposits of the Alps and of the Alpine Epoch in Europe. Springer, Berlin Heidelberg, New York, pp 105-115

Oakes CS, Bodnar RJ, Simonson JM (1990) The system NaCl$\mathrm{CaCl}_{2}-\mathrm{H}_{2} \mathrm{O}$. 1. The ice liquidus at $1 \mathrm{~atm}$ total pressure. Geochim Cosmochim Acta 54:603-610

Ohmoto H (1986) Stable isotope geochemistry of ore-deposits. Rev Miner 16:491-559

Ohmoto H, Rye RO (1979) Isotopes of sulfur and carbon In: Barnes HL (ed) Geochemistry of hydrothermal ore deposits Wiley, pp 509-567

Paniagua A, Fontbote J, Fenoll P, Fallick AE, Moreiras D, Corretge L (1993) Tectonic setting, mineralogical characteristics, geochemical signatures and age dating of a new type of epithermal carbonate-hosted, precious metal-five element deposits: the Villamanin area, Cantabrian zone, (Northern Spain). In: Fenoll P, Torres J, Gervillia F (eds) Current research in geology applied to ore deposits. Granada, pp 531-534

Perry EC, Tan FC (1972) Significance of oxygen and carbon isotope determinations in early Precambrian cherts and carbonate rocks in southern Africa. Bull Geol Soc Am 83:647-664

Plumlee GS, Leach DL, Hofstra AH, Landis GP, Rowan EL, Viets JG (1994) Chemical reaction path modeling of ore deposition in Mississippi Valley-type $\mathrm{Pb}-\mathrm{Zn}$ deposits of the Ozark Region, U.S. Midcontinent. Econ Geol 89:1361-1383

Pohl W (1990) Genesis of magnesite deposits-models and trends. Geol Rundschau 79/2:291-299

Pohl W, Siegl W (1986) Sediment-hosted magnesite deposits. In: Wolf KH (ed) Handbook of stratabound and stratiform ore deposits. Elsevier, Amsterdam, 14:223-310

Roedder E (1984) Fluid inclusions. Rev Miner 12:644

Rosenbaum J, Sheppard SMF (1986) An isotopic study of siderites, dolomites and ankerites at high-temperatures. Geochim Cosmochim Acta 50:1147-1150
Sanchez-España J, Garcia de Cortazar A, Gil P, Velasco F (2002) The discovery of the Borobia world-class stratiform magnesite deposit (Soria, Spain): a preliminary report. Miner Depos 37:240-243

Schultz LG (1964) Quantitative interpretation of mineralogical composition from X-ray and chemical data for the Pierre Shale. U.S. Geol. Surv., Prof. paper 391-C:31

Sheppard SMF, Schwarz HP (1970) Fractionation of carbon and oxygen isotopes and magnesium between coexisting metamorphic calcite and dolomite. Contrib Mineral Petrol 26:161-198

Sibley DF, Gregg JM (1987) Classification of dolomite rock textures. J Sediment Petrol 44:967-975

Spiro B, Tornos F, Shepherd TJ (1995) Stable isotope characterization of barren and mineralized tardi-Hercynian hydrothermal carbonates in the Cantabrian zone (N Spain). In: Pasava J, Kribek B, Zak K (eds) Mineral deposits: from their origin to environmental impacts. Rotterdam, Balkema, pp 75-78

Stamatakis MG (1995) Occurrence and genesis of huntite hydromagnesite assemblages, Kozani, Greece-important new white fillers and extenders. Trans Inst Min Metall 104:b179-b186

Sun SS, McDonough WF (1989) Chemical and isotopic systematics of oceanic basalts: implications for mantle composition and processes. In: Saunders AD, Norry MJ (eds) Magmatism in the ocean basins. Geological Society of London, Special Publication 42, pp 313-345

Tornos F, Spiro BF (2000) The geology and isotope geochemistry of the talc deposits of Puebla de Lillo (Cantabrian Zone, Northern Spain). Econ Geol 95(6):1277-1296

Valley JW (1986) Stable isotope geochemistry of metamorphic rocks. Rev Miner 16:445-486

Vanko DA, Bodnar RJ, Sterner SM (1988) Syhthetic fluid inclusions 8. Vapor saturated halite solubility in part of the system $\mathrm{NaCl}-\mathrm{CaCl}_{2}-\mathrm{H}_{2} \mathrm{O}$, with application to fluid inclusions from oceanic hydrothermal systems. Geochim Cosmochim Acta 52:2451-2456

Veizer J, Hoefs J (1976) The nature of $\mathrm{O}^{18} / \mathrm{O}^{16}$ and $\mathrm{C}^{13} / \mathrm{C}^{12}$ secular trends in sedimentary carbonate rocks. Geochim Cosmochim Acta 40:1387-1395

Veizer J, Ala D, Azmy K, Bruckschen P, Buhl D, Bruhn F, Carden GAF, Diener A, Ebneth S, Godderis Y, Jasper T, Korte G, Pawellek F, Podlaha OG, Strauss H (1999) Sr-87/Sr-86, $\delta C^{13}$ and $\delta \mathrm{O}^{18}$ evolution of Phanerozoic seawater. Chem Geol 161:59-88

Velasco F, Pesquera A, Arce R, Olmedo F (1987) A contribution to the ore genesis of the magnesite deposit of Eugui, Navarra (Spain). Miner Depos 22:33-41

Velasco F, Herrero JM, Yusta I, Alonso JA, Seebold I, Leach D (2003) Geology and geochemistry of the Reocin zinc-lead deposit, Basque-Cantabrian basin, northern Spain. Econ Geol 98:1371-1396

Walter R (1968) Die Geologie in der Nordöstlichen Provinz Lugo ((Nordwest Spanien). Geotekton Forsch 27:3-70

Zheng YF (1999) Oxygen isotope fractionation in carbonate and sulfate minerals. Geochem J 33:109-126 